\title{
Milestones in Functional Titanium Dioxide Thermal Spray Coatings: A Review
}

\author{
M. Gardon and J.M. Guilemany
}

(Submitted April 30, 2013; in revised form January 20, 2014)

\begin{abstract}
Titanium dioxide has been the most investigated metal oxide due to its outstanding performance in a wide range of applications, chemical stability and low cost. Coating processes that can produce surfaces based on this material have been deeply studied. Nevertheless, the necessity of coating large areas by means of rapid manufacturing processes renders laboratory-scale techniques unsuitable, leading to a noteworthy interest from the thermal spray (TS) community in the development of significant intellectual property and a large number of scientific publications. This review unravels the relationship between titanium dioxide and TS technologies with the aim of providing detailed information related to the most significant achievements, lack of knowhow, and performance of $\mathrm{TS}^{\mathrm{TiO}_{2}}$ functional coatings in photocatalytic, biomedical, and other applications. The influence of thermally activated techniques such as atmospheric plasma spray and high-velocity oxygen fuel spray on $\mathrm{TiO}_{2}$ feedstock based on powders and suspensions is revised; the influence of spraying parameters on the microstructural and compositional changes and the final active behavior of the coating have been analyzed. Recent findings on titanium dioxide coatings deposited by cold gas spray and the capacity of this technology to prevent loss of the nanostructured anatase metastable phase are also reviewed.
\end{abstract}

Keywords atmospheric plasma spray (APS), biomaterials, cold spray, electrically conductive coatings, nanostructured materials, photocatalysts, $\mathrm{TiO}_{2}$

\section{Introduction}

\subsection{Metal Oxide Passive Layers}

The feasibility of deposition of metal oxide coatings by thermal spray (TS) resulted from a huge research effort that led to a considerable number of applications and industrial solutions. The most important feature of this material lies in its provision of hardness, wear resistance, and corrosion resistance to certain substrates that lack these characteristics. Providing enhanced mechanical properties to either ductile or more easily oxidizable materials, or to some ceramics and polymers, ensures an increased working life of such bulk materials. Moreover, the characteristics of TS technologies make it possible to form protective metal oxide surfaces via a cost-effective and rapid manufacturing route, easing the scale-up of the final product.

Quite a large number of contributions are available as disclosure patents. Polidor (Ref 1) proposed the protection of refractory parts in machinery used for casting of steel by means of an atmospheric plasma spray (APS) metal oxide coating. The protective coating was not only

M. Gardon and J.M. Guilemany, Thermal Spray Centre, University of Barcelona, Barcelona, Spain. Contact e-mail: mgardon@cptub.eu.

more resistant to the corrosive and erosive effects of molten slag and steel, but also resisted thermal fatigue due to the expansion occurring during the process. Makoto et al. (Ref 2) described a wear-resistant surface that could be applied onto the inside face of the cylinder bore of an engine. The coating composition was based on chromium oxide dispersed in $\mathrm{Fe}$ and Mo. In a more detailed way, many authors have reported in scientific journals the deposition of metal oxide coatings by TS for application as passive protective coatings. Rosso et al. (Ref 3) studied the corrosion resistance and properties of metallic pump pistons coated with different percentages of aluminum oxide and titanium dioxide. The authors reported high corrosion resistance in both saline and acid environments, which could be partly attributed to the lack of interconnected pores that would offer corrosive media a preferential path to reach the substrate. A slight addition of titania (3\%) to alumina provided higher toughness to the coating. The mechanical properties of APS coatings starting from nanostructured $\mathrm{Al}_{2} \mathrm{O}_{3} / \mathrm{TiO}_{2}$ feedstock were described by Wang et al. (Ref 4). Surface worn morphologies for powders with nanosized crystallites were smooth without obvious grooves, providing substantial improvements in wear resistance compared with standard, microstructured powders.

A shift to other spraying technologies and a comparison of the obtained results were then also carried out. Micro- and nanostructured powders based on alumina and titania were sprayed by many authors using APS and highvelocity oxygen fuel (HVOF) spray (Ref 5-12). In general terms, HVOF deposited extraordinarily dense coatings, which provided superior hardness, fracture toughness, and abrasion wear resistance compared with APS coatings. Achieving satisfactory protection of bulk materials at high 
temperatures has also been an important application market. Thus, improving the corrosion resistance of superalloy substrates, such as gas-turbine blades, has been a very distinct line of research and publication (Ref 13-15). Besides this, the high electrical resistivity of these coatings has been exploited to achieve insulating coatings for use in electronics (Ref 16-19).

Moreover, the chemical stability at low or high temperature and the mechanical properties of TS metal oxide coatings may not be the only advantages of these materials. In addition to their demonstrated behavior as passive coatings, their performance as functional active surfaces in many different fields has also attracted the interest of TS scientists and industry professionals.

\subsection{Titanium Oxide Coatings}

Among the many metal oxides that can be used as functional coatings for devices, titanium dioxide has drawn considerable attention. Extracted from minerals such as ilmenite $\left(\mathrm{FeTiO}_{3}\right)$, rutile and anatase (which, together with brookite, are polymorphic crystal structures of $\left.\mathrm{TiO}_{2}\right)$, perovskite $\left(\mathrm{CaTiO}_{3}\right)$, and titanite $\left(\mathrm{CaTiSiO}_{5}\right)$, the annual yield of $\mathrm{TiO}_{2}$ grew to above approximately 6 million tons in 2008, and its industrial success is also supported by its lower cost of production compared with other functional metal oxides (Ref 20, 21). Only rutile and anatase play a key role in the applications of $\mathrm{TiO}_{2}$. In both tetragonal structures, a basic building block consists of a titanium atom surrounded by six oxygen atoms in an approximately octahedral arrangement. As can be observed in Fig. 1, the two bonds between oxygen and titanium at the vertices of the octahedron are slightly longer, and in the case of anatase there is a deviation from a $90^{\circ}$ bond angle relative to the other four bonds (Ref 22). From a TS perspective, it is a hard material with high melting point, and a phase transformation from anatase (metastable) to rutile can easily be produced in the jets/flames of TS guns (Table 1). Titanium dioxide coatings are widely used in various applications such as photocatalysis, bone implants, electric devices, renewable energy, and gas sensors. Taking this into account, the unsurprising, gradual transition of titanium dioxide coating materials from protective surfaces to active functional components has been welcomed and promoted by the whole TS industry.

\section{2. $\mathrm{TiO}_{2}$ Feedstock}

\subsection{Conventional Powders}

Industrial production of $\mathrm{TiO}_{2}$ is a well-known process carried out by different companies; two main routes are used to obtain titanium dioxide powder. The chloride process is commonly applied, where titanium tetrachloride is oxidized at high temperatures and pressures in a flame or pure oxygen plasma to produce titanium dioxide (Ref 28). On the other hand, the sulfate process uses sulfuric acid and ilmenite to produce titanyl sulfate. Then, hydrated titanium dioxide is obtained, which has to be dehydrated to obtain the final pure $\mathrm{TiO}_{2}$ (Ref 29).

Regarding TS powders, $\mathrm{TiO}_{2}$ feedstock is commonly found as an irregular powder, which is obtained from a fusing and crushing process. Particle size distributions usually range between approximately 10 and $70 \mu \mathrm{m}$, with varying mean and breadth of distribution. Spherical powder is also applied in various guns, being produced by means of an atomization process. Fine distributions or submicron particles may be agglomerated to achieve narrow ranges.

\subsection{Nanopowders}

Since functional $\mathrm{TiO}_{2}$ surfaces obtained by TS are based on the interaction between the solid and either liquids or gases, maximization of these interfaces leads to optimized efficiency in the final performance of the material. Therefore, use of nanostructured grains enhances the specific surface of the functional solid, which increases the output of the material. Nevertheless, using nanostructured feedstock suffers from two main drawbacks. First, environmental regulations related to nanosized materials are especially critical. Furthermore, feeding systems are easily clogged when using nanostructured feedstock. With the aim of solving this issue, the grains must be agglomerated up to microsized ranges, which is typically done by means of spray drying. The main downside is the loss of the nanosized grains during the coating process caused by the melting of the feedstock in conventional TS processes. On the other hand, cold gas spray (CGS) technology has been defined as an excellent alternative for dealing with nanostructured feedstock because melting of the feedstock is avoided. In this case, agglomerated particles are also embedded onto ductile surfaces in order to achieve heterogeneous photoactive coatings.

However, very recently, deposition of thick nano- $\mathrm{TiO}_{2}$ films by means of CGS has been disclosed, opening the possibility of obtaining nanostructured metastable surfaces. Fukumoto and coworkers (Ref 30) proposed that the key step for developing $\mathrm{TiO}_{2}$ powders able to be deposited by CGS was the addition of ammonium sulfate $\left[\left(\mathrm{NH}_{4}\right)_{2} \mathrm{SO}_{4}\right]$ during the hydrolysis of titanyl sulfate $\left(\mathrm{TiOSO}_{4}\right)$ and hydrothermal treatment of the dried powder. When these conditions were applied, a smoother surface of the metal oxide nanoparticles was developed, which could be attributed to more uniform agglomeration. Besides this, certain nanoporosity of the obtained particles was found; transmission electron microscopy (TEM) images revealed a highly oriented aggregated structure. The authors stated that these particles break down on impact onto the substrate due to the nanoporosity induced during their production process. Then, crystals were decoupled, forming unstable newly surfaces, which bonded with their counterparts to develop more stable interfaces, thereby building up the coating. Only $\mathrm{TiO}_{2}$ with this configuration was able to reach coating thicknesses of about $100 \mu \mathrm{m}$ by CGS. In other words, only particles produced by this unique chemical route were able to 
Rutile



Anatase

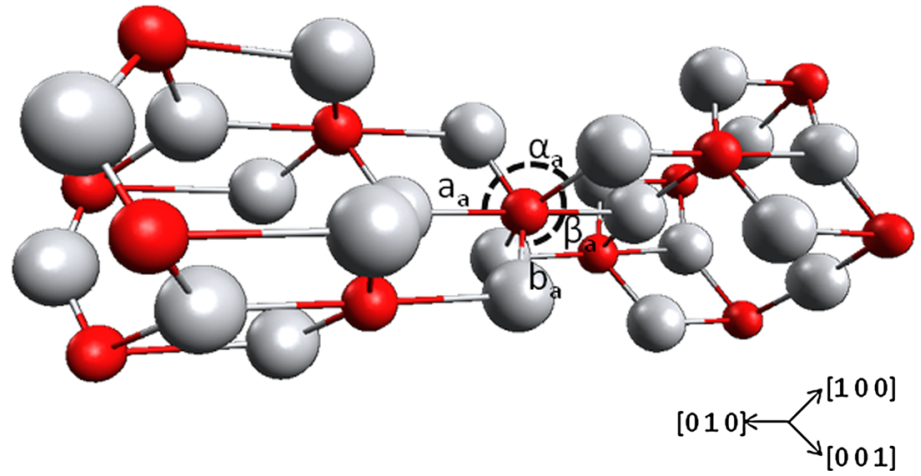

$a_{a}=1,966 \AA$

$b_{a}=1,937 \AA$

$\alpha_{\mathrm{a}}=102,3^{\circ}$

$\beta_{a}=92,6^{\circ}$

Fig. 1 Structures of rutile and anatase; bond lengths and angles of Ti atoms are also shown (Ref 22, 23)

Table 1 Thermophysical properties of rutile and anatase

\begin{tabular}{|c|c|c|c|c|c|c|c|c|}
\hline & $\begin{array}{l}\text { Standard heat } \\
\text { capacity, } \\
\mathbf{J} /\left(\text { mol }^{\circ} \mathbf{C}\right)\end{array}$ & $\begin{array}{l}\text { Coeff. thermal } \\
\text { expansion, } \\
{ }^{\circ} \mathbf{C}^{-1}\end{array}$ & $\begin{array}{l}\text { Melting } \\
\text { point, }{ }^{\circ} \mathbf{C}\end{array}$ & $\begin{array}{c}\text { Thermal } \\
\text { conductivity, } \\
\left.\text { W/(m }{ }^{\circ} \mathbf{C}\right)\end{array}$ & $\begin{array}{l}\text { Density, } \\
\text { g/cm }\end{array}$ & $\begin{array}{c}\text { Vickers hardness } \\
\text { number, } \\
100 \text { g load }\end{array}$ & $\begin{array}{l}\text { Electrical } \\
\text { resistivity, } \\
\Omega \mathrm{cm}\end{array}$ & $\begin{array}{c}\text { Refractive } \\
\text { index }\end{array}$ \\
\hline Rutile & $\begin{array}{l}55.06 \text { at } 100{ }^{\circ} \mathrm{C} \\
(\text { Ref } 22)\end{array}$ & $\begin{array}{r}8.4 \times 10^{-6} \\
(\operatorname{Ref} 23)\end{array}$ & $\begin{array}{l}1,870 \\
(\text { Ref } 24)\end{array}$ & $\begin{array}{l}\text { 6,531 at } 100^{\circ} \mathrm{C} \\
\quad(\text { Ref } 22)\end{array}$ & $\begin{array}{l}4,249 \\
\quad(\operatorname{Ref} 24)\end{array}$ & $\begin{array}{l}\text { 894-974 } \\
\quad \text { (Ref 25) }\end{array}$ & $\begin{array}{c}10^{13} \text { to } 10^{18} \\
\text { (Ref } 27)\end{array}$ & $\begin{array}{c}2,609 \\
(\operatorname{Ref} 27)\end{array}$ \\
\hline Anatase & $\begin{array}{l}55.52 \text { at } 100{ }^{\circ} \mathrm{C} \\
(\text { Ref } 22)\end{array}$ & $\begin{array}{r}8.6 \times 10^{-6} \\
(\operatorname{Ref} 23)\end{array}$ & $\begin{array}{l}1,802 \\
(\operatorname{Ref} 24)\end{array}$ & $\ldots$ & $\begin{array}{l}3,893 \\
\quad(\operatorname{Ref} 24)\end{array}$ & $\begin{array}{l}\text { 616-698 } \\
\quad(\text { Ref 26) }\end{array}$ & $\begin{array}{c}10^{13} \text { to } 10^{18} \\
(\operatorname{Ref} 27)\end{array}$ & $\begin{array}{l}2,488 \\
\quad(\operatorname{Ref} 27)\end{array}$ \\
\hline
\end{tabular}

create chemical bonds on impact. Previously, Yang et al. (Ref 31) also placed considerable importance on the substances used in the agglomeration of small-sized $\mathrm{TiO}_{2}$ grains, stating that the powder may deform under high transient impact pressure due to the organic binder agglomerating the fine particles, leading to deformation that may occur similarly to that of metallic powders in CGS.

\subsection{Suspensions}

Dispersing solid particles in a liquid medium is an alternative for developing TS feedstock, offering excellent opportunities because metastable anatase phase and nanosized grains may be preserved. The main objective of the liquid is to transport the particles to the jet/flame so as to propel the material towards the substrate. Despite the strong interest in this type of feedstock, use of a liquid suspension has some process drawbacks. Particles in liquid suspensions settle over time; nevertheless, the sedimentation velocity is dependent on the particle size. Thus, coarser particles tend to settle quickly, while smaller particles stick together due to electrostatic attraction. Clustered sediments can be found and may even clog the feeding system or the pipeline that connects the feeder with the gun (Ref 32). To achieve efficient suspensions for $\mathrm{TiO}_{2}$ systems, some key steps must be taken into account. First, the solid content (loading) and liquid type have to be selected to achieve suspensions with a particular viscosity and stability. The loading may range between approximately 1 and $30 \%$, and higher values may lead to reduced costs due to decreased deposition time and suspension volume. However, an important alteration in the feed system is required. Besides this, the liquid used for the suspension in TS must be adequately studied; the cooling effect of suspensions in a jet or flame is a fundamental challenge. However, conventional TS processes such as APS and HVOF fed by $\mathrm{TiO}_{2}$ suspensions are of special 
interest, and together with CGS they represent main strategies for achieving well-bonded nanosized anatase coatings.

\section{Features of Thermal Spray Titanium Oxide Coatings}

The temperatures reached in TS processes can result in either undesired phase transformations or alterations in the grain size of the initial $\mathrm{TiO}_{2}$ powder. Moreover, species such as $\mathrm{H}_{2}$ or $\mathrm{O}_{2}$ involved in plasma jets or combustion flames change the stoichiometry of the feedstock. Despite this, TS processes have been developed in this direction with the aim of achieving functional $\mathrm{TiO}_{2}$ coatings. Different techniques that are applied in TS are classified in this work according to how the particles are accelerated, whether they are bonded in a molten, semimolten or solid state, and their capability to produce $\mathrm{TiO}_{2-x}$ coatings.

\subsection{Conventional Processes}

Historically, titanium dioxide powders have been deposited onto different substrates by melting the particles in various types of jets and flames. APS has been extensively used for this purpose; this technology propels molten powder particles towards a substrate by means of a plasma jet. High temperatures of up to $28.000{ }^{\circ} \mathrm{C}$ are reached in such plasma jets, and $\mathrm{TiO}_{2}$ metastable phases such as anatase are transformed to rutile (Ref 33). Different APS techniques are used in either industry or universities and $\mathrm{R}+\mathrm{D}+\mathrm{i}$ centers; conventional APS competes with other technologies such as vacuum plasma spray (VPS) or water-stabilized plasma spray (WPS). Anyhow, in all cases, the starting material is fused and solidified again onto the substrate surface, which leads to an increase in the grain size when using nanostructured materials and the loss of metastable phases. The coefficient of thermal expansion (CTE) mismatch between titanium dioxide and typical stainless-steel substrates may result in vertical cracks in the cross-section of the coatings and even complete decohesion, which can be avoided through precise control of spraying conditions. Besides this, the plasma composition plays a key role not just in the energy transfer to the particles and their propulsion, but also in the capacity to alter the stoichiometry of $\mathrm{TiO}_{2}$. Ohmori et al. (Ref 34) attributed to $\mathrm{H}_{2}$ contained in the plasma jet the phenomenon of deoxidization of titanium dioxide during particle flight. Hydrogen may reduce $\mathrm{Ti}^{4+}$ to $\mathrm{Ti}^{3+}$, which can lead to accumulation of a considerable amount of oxygen vacancies. Figure 2 shows a schematic of the operation with anatase- $\mathrm{TiO}_{2}$ particles in the APS process and a typical obtained coating. It is possible to observe how molten particles of titanium dioxide are propelled as droplets by a mixture of gases $\left(\mathrm{Ar} / \mathrm{H}_{2} / \mathrm{He}\right)$ that have previously flowed through an electric arc, where the plasma is formed. The possible interaction between the feedstock and the species present in the plasma is also represented. The cross-sectional area of a representative coating is exhibited; the classic lamellar structure can be observed, which is caused by different degrees of oxidation of $\mathrm{TiO}_{2}$. A certain porosity is typically obtained in APS coatings when using metal oxides.

If TS processes such as APS or HVOF build up $\mathrm{TiO}_{2}$ coatings by means of completely or partially melting the in-flight particles, nucleation of metastable anatase from the melt should be discussed. Li and Ishigaki (Ref 24) analyzed the nucleation rates of anatase and rutile in $\mathrm{TiO}_{2}$ melt based on the estimated interfacial energy between liquid and solid. The nucleation rate of a spherical nucleus is determined by the interfacial energy between the liquid and solid and the difference in Gibbs free energy per unit volume of liquid and solid phases $\left(\gamma^{\mathrm{L} / \mathrm{S}}, \Delta G_{\mathrm{V}}^{\mathrm{L} / \mathrm{S}}\right)$. Both parameters govern the critical nucleation energy $\left(\Delta G^{*}\right)$, which is exponentially related to the rate of nucleation in a supercooling melt $(I)$. The authors found that, below $2075 \mathrm{~K}$, metastable anatase is formed, while rutile preferentially nucleates between $2075 \mathrm{~K}$ and $2143 \mathrm{~K}$. Namely, anatase is formed under higher cooling rates whereas rutile nucleates under conditions of equilibrium solidification. Zhang and Banfield (Ref 37) had already correlated the thermodynamic phase stability of nanocrystalline titania. It was observed that anatase becomes the stable phase when the particle size decreases to sufficiently low values (ca. $14 \mathrm{~nm}$ ), where the total free energy of rutile is higher than that of anatase. From the point of view of TS technologies, deposition of anatase coatings may be obtained from inflight molten particles at high temperatures when solidified with a high degree of undercooling. However, a second effect must be taken into account: anatase-to-rutile transformation will happen if nucleated anatase particles reside longer in hot areas. Regarding particle size, smaller particles could enhance the anatase content in the coating. Nevertheless, powders are usually agglomerated to achieve suitable flowability in TS feeding systems, which reduces the chance of enhancing the anatase content by this route. Furthermore, greater particle velocity may lead to thinner splats, which can contribute to boost the cooling rate. In this way, TS anatase coatings can be obtained when particle nucleation/solidification occurs away from equilibrium conditions, although larger anatase particles can transform back to rutile due to the liberation of a larger amount of heat of fusion and slower cooling rates, as reported by Pawlowski (Ref 28).

A clear step towards a less thermally aggressive TS technology was made with the development of HVOF spray. In this technology, a combustion reaction between either organic substances (propylene, propane or kerosene) and oxygen or hydrogen and oxygen takes place at high pressure, which expands the combustion products (up to $3000{ }^{\circ} \mathrm{C}$ ) to supersonic velocity through a converging or converging/diverging nozzle, accelerating the powder particles towards the substrate (Ref 33,38 ). Lower temperatures compared with APS and higher kinetic energies are crucial concepts for a partial preservation of metastable anatase phase and avoiding grain growth for nanostructured $\mathrm{TiO}_{2}$ feedstock. Therefore, HVOF technology 


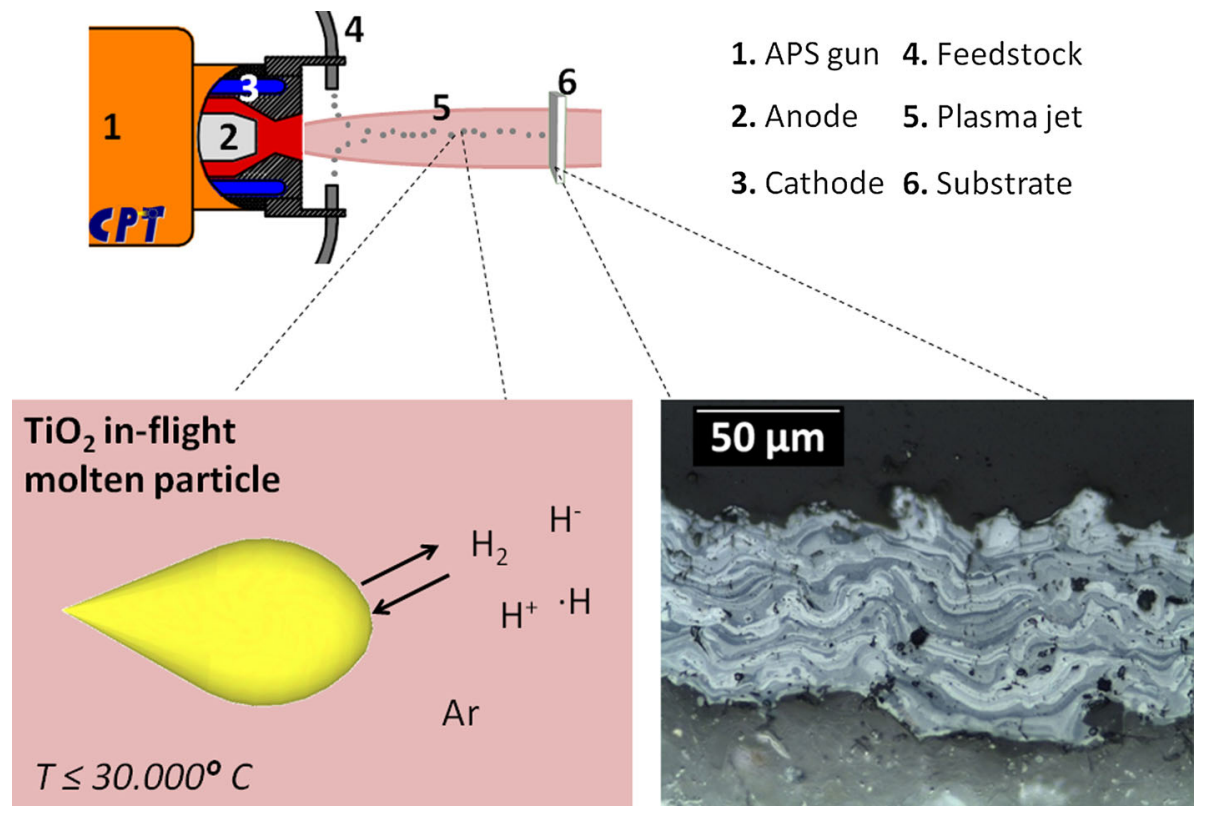

Fig. 2 Schematic of an APS gun (Ref 35), interaction between $\mathrm{TiO}_{2}$ particles and the plasma jet, and a representative obtained coating (Ref 36)

has been widely used to build up titanium dioxide coatings for functional applications in different devices.

Figure 3 shows a schematic of the operation of the $\mathrm{HVOF}$ process with agglomerated nano- $\mathrm{TiO}_{2}$ particles and a typical obtained coating. In this case, the starting powder is not so influenced by the heat involved in the combustion flame, which leads to semimolten in-flight particles. Also in this case, interaction with the species present in the flame can occur and must be taken into account. A cross-section of a typical $\mathrm{HVOF} \mathrm{TiO}_{2}$ coating on steel is shown as well. It can be observed that the lamellar structure is not so visible and the greater velocity of the particles leads to a denser coating. A bimodal aspect is also very common when spraying nanostructured titanium dioxide powders, being composed of molten zones, where there can be a growth in grain size and certain anatase-to-rutile phase transformation, and nonmolten zones, where the starting material is preserved.

\subsection{Suspension Spraying}

Suspensions of a solid in a liquid solvent have also been used as feedstock for APS, being radially injected into the plasma jet. Much effort has been applied in this direction because of the highly attractive results that can be obtained. Solid contained in the suspension may preserve its composition and structure. Therefore, nanostructured metastable anatase coatings can be obtained by this technique. HVOF guns can also use feedstock based on suspensions in the same way that suspension plasma spray (SPS) does (Ref 39). Thus, high-velocity suspension flame spray (HVSFS) was proposed as an even less thermally aggressive TS technology. However, the suspension was injected axially to ensure uniform entrainment and processing of the feedstock in the gas jet, overcoming the typical problems of radial injection (Ref 40).
In any case, both conventional APS and HVOF technologies fed by suspensions lead to well-bonded coatings with low porosity. The main downside of this alternative TS process is the difficulty found in the preparation of the suspensions and the interaction of the suspension with the jet or flame.

\subsection{Cold Gas Spray}

Inevitably, CGS technology is the final step in this evolution from warm technologies towards TS processes that avoid supplying enough heat to the materials involved to result in phase transformation or grain growth. CGS does not need temperature to build up the coating, because the particles adhere to the substrate due to their plastic deformation in solid state. Metallic coatings have been successfully obtained, with subsequent development of great numbers of research papers and commercial applications. This has been feasible because the plastic deformation of metallic particles on impact and the locally released heat lead to shear instabilities of the ductile component (Ref 41, 42). If preservation of the raw microstructure and composition plays a key role in the performance of anatase nanostructured photocatalysts, using such nondegrading TS techniques would be ideal. Thus, CGS appears to be an excellent alternative to other, conventional TS processes. Nevertheless, it does not seem straightforward to produce ceramic coatings by plastically deforming the particles on impact because of the brittleness of such materials.

Gutzmann et al. (Ref 43) considered this method with titanium dioxide powder as the feedstock material. The ceramic particles were sprayed onto titanium, stainless steel, copper, and aluminum alloy. It was found that the substrate was plastically deformed on impact and that the 


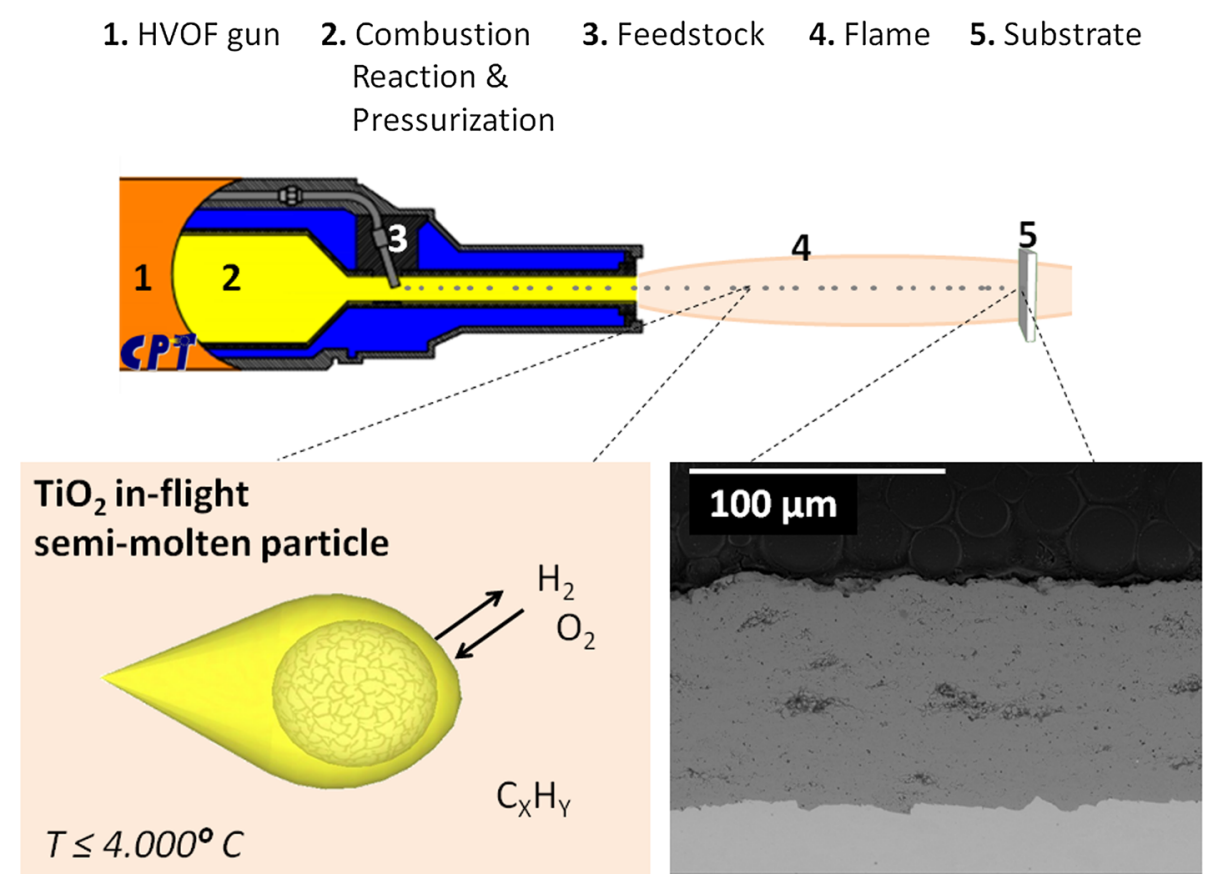

Fig. 3 Scheme of the HVOF gun (Ref 18), interaction between $\mathrm{TiO}_{2}$ particles and the combustion flame, and a representative obtained coating

titanium dioxide particles were mechanically embedded. As the ductility of the substrate was increased, the metallic jetting between the adhered particles increased and fresh metallic surface was formed. Therefore, secondary particles were allowed to bond with these newly formed surfaces. Yang et al. (Ref 31) obtained very similar results previously. In further work, Gutzmann et al. (Ref 44) used a powder based on agglomerated crystallites with size between 5 and $15 \mathrm{~nm}$. The powder was partly sprayed as-received whereas another batch was heat treated. The $\mathrm{TiO}_{2}$ particles that were heat treated bonded more pronouncedly due to shear instabilities at substrate sites, whereas the nontreated material behaved in a more brittle manner and showed internal fracture. It was concluded that, although all the operation parameters influenced the formation of the coating, the powder characteristics had particular significance. Unfortunately, the impossibility of bonding particles together to develop coatings thicker than the particle diameter resulted in thin and intermittent coatings.

On the other hand, thick, homogeneous titanium dioxide films have been successfully achieved using CGS. Different studies by various research groups have led to different conclusions, and general consensus on this relatively new topic has not been attained yet. As previously explained in Sect. 2.2, nano- $\mathrm{TiO}_{2}$ may be produced for deposition by means of a CGS process. Yamada et al. (Ref 45) sprayed $20-\mu \mathrm{m}$ agglomerated particles of pure anatase with crystalline structure onto soft steel, stainless steel, and ceramic tile, obtaining thicknesses of more than $100 \mu \mathrm{m}$. There was no embedding of the particles into the substrate surface, which suggested the possibility of chemical bonding. This was confirmed by transmission electron microscopy (TEM), where it could be observed that the particles were connected as a single crystal. The nanoscale structure of the powder led to certain porosity, which enabled breakage of the particles on impact, leading to the build-up of the coating. In later work, the reactivity and hardness of different substrate materials were studied to understand the deposition behavior (Ref 46). The findings showed that substrates with lower standard electrode potential tended to form a thin film of oxide on the surface, which hindered the deposition of the cold-sprayed particles. Therefore, low hardness and reactivity towards oxygen are required substrate properties for achieving good adhesion of cold-sprayed $\mathrm{TiO}_{2}$ coatings.

This background inevitably leads to a justifiable debate among TS scientists and industry professionals regarding synthesis of functional hard materials that can be deposited by CGS using new approaches and how such powders should be designed. Bearing these concepts in mind, solidstate anchoring of nano- $\mathrm{TiO}_{2}$ particles by CGS onto a substrate may be achieved by mechanical embedding or possibly chemical bonding among particles and between particles and the substrate when an appropriate synthesis route and spraying conditions are applied. Figure 4 shows a schematic of the operation of the CGS process with agglomerated nanostructured anatase- $\mathrm{TiO}_{2}$ particles. First, scanning electron microscopy shows a tilted sample of $\mathrm{TiO}_{2}$ particles embedded into an aluminum substrate. Then, a continuous CGS anatase coating is also shown, deposited onto an intermediate APS $\mathrm{TiO}_{2-x}$ coating. 


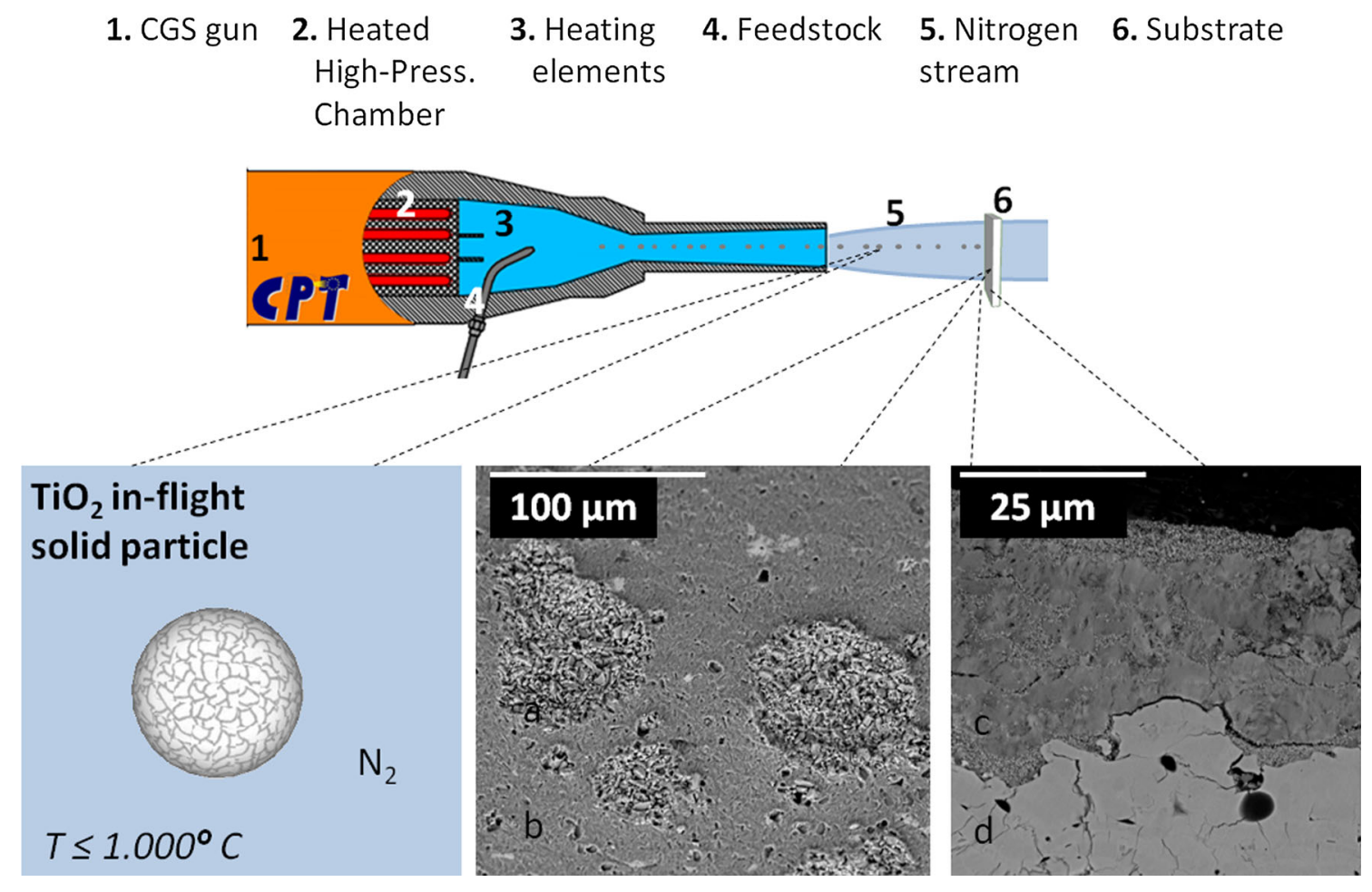

Fig. 4 Scheme of a CGS gun (Ref 18), interaction between $\mathrm{TiO}_{2}$ particles and the nitrogen stream, and representative obtained coatings: (a) $\mathrm{TiO}_{2}$ inlaid particles, (b) aluminum, (c) nanostructured $\mathrm{TiO}_{2}$ continuous coating, and (d) APS $\mathrm{TiO}_{2-x}$ coating

\section{Applications}

\subsection{Photocatalysis}

4.1.1 Photocatalytic Degradation of Contaminants. Among the distinct systems of photocatalysis, application of a coating as an active layer is still the commonest way to achieve satisfactory efficiency. However, formation of photoactive layers on a substrate is not trivial, especially if large functional areas must be coated. With the purpose of solving this, TS processes appeared during the last decade as a group of techniques able to accelerate powder particles towards a substrate to build up photocatalytic coatings with the capacity of degrading pollutants, and this has even become the flagship application of functional TS $\mathrm{TiO}_{2}$.

Since the pioneering paper by Fujishima and Honda (Ref 47) on water splitting by means of the photocatalytic activity of $\mathrm{TiO}_{2}$, a great amount of research and publication of papers and patents has been carried out in this field. When irradiating titanium dioxide with ultraviolet A (UVA) light, holes are photogenerated with a redox potential of $+2.53 \mathrm{~V}$ versus the standard hydrogen electrode $(\mathrm{SHE})$ in $\mathrm{pH} 7$ solution. Hydroxyl radicals $(\cdot \mathrm{OH})$ are produced after reacting with water $(+2.27 \mathrm{~V})$. In addition, the excited electrons have a redox potential of $-0.52 \mathrm{~V}$, which is negative enough to reduce $\mathrm{O}_{2}$ to $\mathrm{O}_{2}{ }^{-}$or $\mathrm{H}_{2} \mathrm{O}_{2}$ (Ref 48). These highly reactive species formed/ adsorbed at the surface of titanium dioxide are then able to degrade different kinds of contaminant via many dis- tinct reaction mechanisms. However, coating processes activated by temperature may result in a decrease in the effectiveness of the photocatalyst because less active phases can be found in the coating. In the case of $\mathrm{TiO}_{2}$, this is a significant shortcoming as the metastable anatase phase is considered to have enhanced photocatalytic activity compared with rutile. The thermal condition is also significant when the starting feedstock has nanostructured grains. Working with crystallite size below $100 \mathrm{~nm}$ provides a considerable increase in the specific surface of the coating material, boosting the interaction of the active solid with the species to degrade. Thus, melting and resolidification of the powder are supposed to increase the grain size of the coating, namely to decrease the specific area of the active material.

Many authors have worked on $\mathrm{TiO}_{2}$ deposition by means of APS with the intention of utilizing its wear, corrosion, and erosion resistance (Ref 49-51). They also dealt with application of this coating material as a photocatalyst and the special issues of loss of anatase phase and grain size growth. In a first work starting from spraydried anatase powder (Ref 52), X-ray diffraction (XRD) results demonstrated that the amount of the metastable phase in the coatings depended strongly on the plasma power and weakly on the nature of the plasma. It was found that alteration of the plasma power with a standard $\mathrm{Ar} / \mathrm{H}_{2}$ mixture and a constant cooling rate increased the anatase content from 35 to $50 \%$. Later, faced with the impossibility of boosting the amount of this metastable 
phase, the same authors selected SPS to build up photocatalytic $\mathrm{TiO}_{2}$ coatings (Ref 53). In this work, the photocatalytic efficiency of SPS samples starting from aqueous and alcoholic-based suspensions was evaluated for degradation of nitrogen oxides. A significant phase transformation from anatase to rutile and poor decomposition of the pollutants were observed when coatings were obtained by SPS using an alcoholic-based suspension. However, the crystallite size and anatase content were quite well preserved in samples resulting from aqueous slurry, leading to higher conversion rates of nitrogen oxides (40\% for NO, $15 \%$ for $\mathrm{NO}_{x}$ ). The same pollutant removal was proposed by Coddet and coworkers (Ref 54) in another published article comparing the performance of APS and SPS using spray-dried powders. Plasma-sprayed deposits had activity below $2 \%$, caused by an almost complete loss of the anatase phase. However, SPS samples exhibited activities of $50 \%$ and up to $30 \%$ for degradation of $\mathrm{NO}$ and $\mathrm{NO}_{x}$, respectively, better than the starting powders and even APS coatings. This was again attributed to preservation of the anatase phase, elimination of powder impurities (e.g., organic binders), and cleaning of the particle surfaces when crossing the plasma. Other authors have also pointed out that the decrease of the photocatalytic efficiency of APS $\mathrm{TiO}_{2}$ coatings was caused by loss of anatase, although the degradation of many different contaminants has been studied (Ref 55-58).

On the other hand, there are some studies where it has been stated that certain heterogeneous photocatalytic reactions on $\mathrm{TiO}_{2}$ may not exclusively depend on the anatase content. Starting from nanostructured anatase powders, Kozerski et al. (Ref 59) obtained SPS rutile coatings with low content of anatase. No correlation was found between the amount of the metastable phase and the photocatalytic efficiency of the coating. Moreover, a SPS $\mathrm{TiO}_{2}$ coating with only $1.6 \%$ anatase had specific photocatalytic activity greater than commercial standard material. This discrepancy from the general consensus in the scientific community was attributed by the authors to other factors that may have influenced the TS photocatalytic $\mathrm{TiO}_{2}$ coatings such as the presence of hydroxyl radicals and coating characteristics such as porosity, roughness or thickness, in agreement with Ctibor et al. (Ref 60). Furthermore, Bannier et al. (Ref 61) suggested that the amount of anatase and the photocatalytic efficiency were not well correlated since the anatase phase is usually determined by X-ray diffraction, which does not correctly represent its value on the top surface of the coating. More recently, Ctibor et al. (Ref 62) studied the photocatalytic behavior of titanium dioxide coatings sprayed by a water-stabilized plasma (WSP) gun, which has higher powder processing rates of $\mathrm{TiO}_{2}$ compared with conventional APS/SPS torches, higher plasma temperatures, and the presence of ionized oxygen in the plasma. In this study, increased photodegradation of acetone was attributed to coatings that had higher porosity, namely higher surface area and higher amount of hydroxyl groups, which may act as centers for photocatalytic reactions.

Visible light photoefficiency is also an important target for $\mathrm{TiO}_{2}$ coatings. Anion doping by nitrogen has been extensively studied; absorption in the visible light region is achieved, leading to better exploitation of solar irradiance. Thus, powders with this property are starting to be demanded by TS. Recently, Mauer et al. (Ref 63) used SPS to spray anatase powders mixed with TiN milled down to particle diameter of $5 \mu \mathrm{m}$. Photothermal deflection spectroscopy showed higher photoexcitation for nitrogendoped SPS $\mathrm{TiO}_{2}$ compared with undoped samples, which is supposed to provide improved photoactivity. Although no degradation of contaminants was reported, the results open an interesting research path in atmospheric and suspension plasma spraying.

The irreversible anatase-to-rutile phase transformation and the efficiency of APS/SPS anatase photocatalysts have been widely discussed. Nevertheless, many scientific works are still being published, and this endeavor does not seem to be slowing down (Ref 64-66).

Attempts to compare the mechanical properties of micro- and nanostructured $\mathrm{TiO}_{2}$ coatings sprayed by APS and HVOF have been carried out in different studies (Ref $67,68)$. HVOF coatings obtained from nanostructured $\mathrm{TiO}_{2}$ feedstock powders showed enhanced abrasion resistance, bond strength, crack propagation resistance, and fatigue strength when compared with microstructured APS and HVOF samples. These results support and agree with previous and subsequent outcomes obtained from research and testing of the functional photocatalytic behavior of HVOF nano- $\mathrm{TiO}_{2}$. Toma et al. (Ref 69) suggested that $\mathrm{TiO}_{2}$ coatings obtained by HVOF, APS, and vacuum plasma spray (VPS) could be used for photocatalytic $\mathrm{NO}_{x}$ removal. In this preliminary study, the photocatalytic performance of HVOF coatings was not observed, but it was reported that anatase powder provided better photocatalytic activity than the sprayed coatings. The authors again placed deep importance on the anatase phase, but also the porosity of the samples, which is able to increase the reactive surface and photocatalytic efficiency. Subsequently, a further study focused on nanostructured $\mathrm{TiO}_{2}$ and $\mathrm{Al} / \mathrm{TiO}_{2}$ coatings built up by $\mathrm{HVOF}$, and their performance in degrading $\mathrm{NO}_{x}$ was presented (Ref 70). Coatings initially exhibited poor performance due to an unexpected transformation of anatase to rutile phase. This was attributed to the axial injection of the powders in the HVOF process. Therefore, a modified HVOF spray gun was elaborated; concretely, the powders were injected externally into the flame. Consequently, an increase of the anatase content in the coatings up to $65 \%$ was found, and also the grain size was preserved $(18 \mathrm{~nm})$. Regarding the $\mathrm{Al} /$ nano- $\mathrm{TiO}_{2}$ mixture, a certain amount of $\mathrm{Al}_{2} \mathrm{O}_{3}$ was observed, and in this case a higher ratio of anatase was obtained. This was explained based on the fact that part of the flame heat was used to melt and maybe vaporize aluminum particles. $\mathrm{NO}-\mathrm{NO}_{x}$ were degraded using nano- $\mathrm{TiO}_{2}$ and $\mathrm{Al} /$ nano- $\mathrm{TiO}_{2}$ photocatalysts at conversion rates of 24-13 and 43-19\%, respectively. The authors suggested that aluminum could have contributed to the charge separation during ultraviolet irradiation, enhancing the photocatalytic activity of the coating.

Colmenares-Angulo et al. (Ref 71) studied the influence of reduced stoichiometries of APS and HVOF 
titanium dioxide coatings on photodegradation of $50 \mathrm{mg} / \mathrm{L}$ methylene blue. XRD analysis showed the presence of $\mathrm{Ti}_{8} \mathrm{O}_{15}$ phase in the as-prepared HVOF and APS samples, which could indicate reduction of $\mathrm{TiO}_{2}$ during the coating process, because the existence of reduced phases in the starting feedstock was not reported. Obtained samples were heat treated in air at $650{ }^{\circ} \mathrm{C}$ for a period of $48 \mathrm{~h}$ to reoxidize the partially reduced $\mathrm{TiO}_{2}$, as confirmed by XRD phase analysis. Then, thermally treated and as-sprayed APS and HVOF samples were tested as photocatalysts. After $48 \mathrm{~h}$ of heterogeneous photocatalysis, untreated coatings did not exhibit any significant activity. On the other hand, the reoxidized APS and HVOF samples showed efficiencies of almost 28 and $38 \%$, respectively. It was concluded that oxygen vacancies in HVOF and APS $\mathrm{TiO}_{2}$ coatings are not desired in photocatalytic applications because they act as charge recombination centers. The higher efficiency of the HVOF sample was attributed to its greater anatase content. In this process, defect states are reoxidized, increasing the photocatalytic efficiency, but the anatase-to-rutile phase transformation also occurs, which may have a negative effect on the desired performance.

Yang et al. (Ref 72) adjusted the HVOF spraying conditions with the aim of partially melting the starting anatase particles, demonstrating photocatalytic efficiency. The authors fixed a constant oxygen pressure and flow and raised the fuel (propane) gas flow in various steps to increase the flame temperature. It was found that the anatase content was still $40 \%$ when injecting the largest amount of fuel. In these conditions, the particles were completely molten and impacted on the substrate surface at higher velocities, which led to thinner splats. Then, rapid cooling and solidification may result in preservation of the anatase phase, in agreement with anatase nucleation mechanisms explained previously. The photocatalytic performance of the samples was tested by phenol degradation in aqueous phase. The highest rates of pollutant removal were obtained with the coating built up using the highest fuel ratio, which had a considerable amount of rutile phase. This dependence was quite different compared with results reported by other authors. Once again, the microstructural features of the $\mathrm{TiO}_{2}$ coatings deposited by TS processes could play a key role, although this was not an issue reviewed in this article. Later, Yang et al. (Ref 73) tried to clarify the dominant microstructural characteristic for the photocatalytic activity of $\mathrm{HVOF} \mathrm{TiO}_{2}$ coatings starting from anatase and rutile powders. Increase of the anatase content in the HVOF coating led to higher photocatalytic activity, but with a nonlinear relation. The maximum efficiency was obtained by starting with anatase powder and operating at a low fuel gas flow, which resulted in a larger amount of anatase in the sprayed material and a higher surface area due to the lower melting of the nanostructured powder. Nevertheless, when starting from rutile powder and operating at high fuel gas flow, a coating with $50 \%$ anatase was obtained, which showed relatively low photocatalytic activity. The authors explained that thermally powered conditions could: (i) transform the upper layer of the coating to rutile, which decreases the area of material where the expected interaction occurs, and (ii) decrease the surface area of the sample. In another work, Nakade et al. (Ref 74) compared $\mathrm{TiO}_{2}$ feedstocks with different grain sizes, studying the photocatalytic degradation of $\mathrm{CH}_{3} \mathrm{CHO}$ gas with the obtained HVOF samples. The $\mathrm{TiO}_{2}$ coating obtained with $30-\mathrm{nm}$ agglomerated powder showed the highest degradation rate, being attributed once again to the higher anatase content in this coated sample.

In this way, in HVOF deposition of $\mathrm{TiO}_{2}$ coatings, one must adequately balance two effects when adjusting the fuel gas flow: (a) prevention of anatase-to-rutile phase transformation even at the top surface of the coating, and (b) provision of large specific surface area. This experimental procedure ensures the development of efficient titanium dioxide materials due to the photochemical properties of the predominant anatase phase and the existence of more active centers where heterogeneous catalytic reactions can occur. Strategies related to prevention of undesired phase transformation may be based on achieving in-flight molten particles at high temperatures with high velocities in HVOF, which would lead to thin splats of liquid $\mathrm{TiO}_{2}$, facilitating anatase nucleation under high cooling rates.

Gadow et al. (Ref 75) deposited nanostructured $\mathrm{TiO}_{2}$ by HVSFS to correlate the spraying conditions with the content of nanostructured metastable phase in the coating. From XRD data it could be stated that the coating consisted mainly of anatase (approximately $75 \%$ ) and the rest of the material was rutile. A further work involved complete mechanical characterization of the samples and the application of HVSFS nano- $\mathrm{TiO}_{2}$ coatings as photocatalysts for degradation of $1 \mathrm{ppm}$ indigo aqueous solution (Ref 76). The obtained microstructure was based on three different types of regions: (i) fully molten material, (ii) well-recognizable nanosized particles, and (iii) large and thick lamellae with perceivable columnar microstructure. The photocatalytic performance of HVSFS nano- $\mathrm{TiO}_{2}$ samples was compared with that of APS and HVOF nano$\mathrm{TiO}_{2}$. The results showed that samples fed by suspensions had superior activity for degrading indigo aqueous solution. The HVSFS spraying conditions could be adjusted to enhance the amount of nonmolten nanoparticle agglomerates, which boosted the photocatalytic process. However, worse mechanical and tribological properties were obtained when using these spraying parameter values, which was also in agreement with Toma et al. (Ref 77, 78).

Anyhow, successful applications have been reported such as photocatalytic degradation of dichloroacetic acid using anatase- $\mathrm{TiO}_{2}$ coatings prepared by APS, HVOF, and CGS (Ref 79). It was found that the photocatalytic performance of such coatings obtained by thermally nonaggressive techniques such as CGS was at least three times higher than when using HVOF or APS. It was argued that techniques that involved high temperatures convert the anatase content to rutile, thereby decreasing the efficiency of the photocatalyst. Gardon et al. (Ref 80) built up CGS nanostructured anatase coatings on an APS $\mathrm{TiO}_{2-x}$ bond coat previously deposited onto stainless-steel

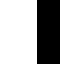


cylinders. Nano- $\mathrm{TiO}_{2}$ coatings were not adequately bonded onto steel. Therefore, APS $\mathrm{TiO}_{2-x}$ bond coats were previously sprayed with the aim of providing a surface with certain hardness, roughness, and chemical composition that could facilitate the breakage of agglomerated nano- $\mathrm{TiO}_{2}$ particles and their adhesion on impact. CGS nano- $\mathrm{TiO}_{2}$-coated cylinders were placed into glass tubular reactors, and their photocatalytic performance was tested using phenol and formic acid as contaminants in aqueous phase; the obtained results were compared with sol-gel nano- $\mathrm{TiO}_{2}$ coatings. Both pollutants were successfully degraded, and CGS photocatalysts showed comparable results to sol-gel material, demonstrating that photoactive $\mathrm{TiO}_{2}$ surfaces obtained by CGS technology can compete with commercial standards.

4.1.2 Bactericidal Effect. The bactericidal effect of HVOF $\mathrm{TiO}_{2}$ coatings can also be exploited, and certain results are available based on the conservation of the photocatalytic performance of the material. Starting from nanostructured anatase powders, Jeffery et al. (Ref 81) obtained $\mathrm{TiO}_{2}$ coatings with $20 \%$ anatase. Bacterial cell solution $(50 \mu \mathrm{L})$ containing Pseudomonas aeruginosa was pipetted onto 304 stainless-steel substrate and HVOF $\mathrm{TiO}_{2}$ coatings. Clear photocatalytic performance was obtained when comparing the coated sample with the metallic substrate. However, a low kill rate of $24 \%$ after 120 min was found. This could be caused by the use of white light, which is less energetic than UV light, and the fact that the bacteria could form/embed themselves in a protective biofilm matrix. The authors also attributed the photocatalytic performance of the coatings to anatase phase. Thus, an increase of the performance of the bactericidal effect of the coated samples was expected when optimizing the amount of anatase phase in the coatings in further studies.

The bactericidal effect of CGS anatase coatings was also studied by Kliemann et al. (Ref 82). A kill rate of $99.99 \%$ was obtained after $5 \mathrm{~min}$ of exposure of $P$. aeruginosa bacteria to UV light with peak intensity at $360 \mathrm{~nm}$. A certain stagnation of the decay of the bacteria was found, which could be attributed to noncoated areas present due to the impossibility of covering all the surface of the substrate by means of anchoring $\mathrm{TiO}_{2}$ particles.

4.1.3 Dye-Sensitized Solar Cells. Fan et al. (Ref 83) deposited nano- $\mathrm{TiO}_{2}$ powders of $25 \mathrm{~nm}$ and $200 \mathrm{~nm}$ diameter by CGS, but in this case the material was sprayed in a vacuum chamber (vacuum cold spray, VCS) onto indium tin oxide (ITO) conducting glass and stainless steel to study the viability of producing dye-sensitized solar cells (DSSC). Homogeneous nanocrystalline anatase coatings were obtained with thickness of some tens of microns and exhibited good adhesion to the substrate. The coatings were dense but showed certain porosity, which suggested that they were formed mainly by agglomeration of small particles upon impact at high velocity. An average Vickers microhardness value much lower than that of sintered $\mathrm{TiO}_{2}$ bulk was obtained, behaving as a ceramic green body preform with weak bonding between particles. A preliminary study of DSSC performance showing high conversion efficiency was mentioned but was not included in this report. Afterwards, photoelectrochemical measurements were carried out under illumination by a metalhalide lamp (Ref 84). Nano- $\mathrm{TiO}_{2}$ powders were directly sprayed and also mixed with poly-ethylene glycol (PEG) before spraying; obtained samples were annealed at $450{ }^{\circ} \mathrm{C}$. PEG was removed during annealing, which created more porosity. This led to: (i) larger pores where transfer of ions in electrolyte was promoted through diffusion, and (ii) increased adsorption of dye per volume of nano- $\mathrm{TiO}_{2}$ coating. Finally, the conversion efficiency of $\mathrm{TiO}_{2}$ powders mixed with PEG was higher than the values obtained starting from pure $\mathrm{TiO}_{2}$. In a later work, the same authors repeated the above experiments but in this case without the presence of PEG (Ref 85). In that report, annealing was clearly defined to be crucial after building up the coatings. This postsintering step improved the contact among the VCS nano- $\mathrm{TiO}_{2}$ deposited particles and had a considerable effect on the solar energy conversion. An increase from 2.4 to $4.9 \%$ was achieved, suggesting the importance of sintering steps after spraying to boost the interlocking of nano- $\mathrm{TiO}_{2}$ particles. More recently, $\mathrm{Li}$ and coworkers (Ref 86 ) also studied the formation of the pore structure and its influence on the mass transport properties of VCS nano- $\mathrm{TiO}_{2}$ coatings. Bimodalsized pores present in the coatings deposited using strengthened powder contributed to a higher diffusion coefficient, which led to enhanced photovoltages of the solar cells.

Apart from these works, no more notable contributions to the state of the art of DSSC are available. However, the expansion of cold spray technology is expected to reach nontraditional markets such as fabrication of complex conductive patterns in solar cells for photovoltaic applications (Ref 87). Therefore, further attempts establishing encouraging performance are awaited.

\subsection{Biomaterials}

Although the role of TS titanium dioxide coatings in biomedical implants does not seem to rely on such a sophisticated interaction as that developed for photocatalysis, they can also be classified as functional. The exceptional anticorrosive and biocompatibility properties of titanium are due to the thin protective oxide layer formed on the metallic surface (Ref 88, 89). Therefore, designing bone implants directly with $\mathrm{TiO}_{2}$ instead of working with Ti has caught the attention of the TS field. Cells respond to the amount and area of proteins that are available for binding onto an implant (Ref 90). To harness this effect, it was proposed to use biomaterials coated with TS $\mathrm{TiO}_{2}$ nanostructured surfaces. Titanium dioxide nanotextures could provide the formation of a biomimetic structure, where proteins such as fibronectin may be largely anchored. This biomimetism may increase the adhesion strength of osteoblast cells on the coating surface, which would contribute to enhanced biocompatibility of TS nano- $\mathrm{TiO}_{2}$ coatings (Ref 91). Thus, taking into account the importance of the physical structure of the biomaterial surface, much scientific research has focused on its modification. Moreover, TS processes can skip this step, 
directly providing the above-discussed material. Regarding phase composition, He et al. (Ref 92) found that, for a constant nanoroughness, the bioactivity of anatase or rutile depended on its hydrophilicity. Anatase phase exhibited better biocompatibility in comparison with rutile, mainly due to its surface wettability. This is also in agreement with Yamamoto et al. (Ref 93). In contrast, Rossi et al. (Ref 94) compared sol-gel-derived anataseand rutile-structured $\mathrm{TiO}_{2}$ coatings in soft-tissue environments, observing no major differences in tissue response.

Plasma spray has contributed to biomedical applications, with successful results particularly using hydroxyapatite (HA) coatings on titanium implants. However, the long-term stability of these coatings may be questionable. Consequently, titanium dioxide has been widely added to hydroxyapatite powders with the aim of improving the mechanical stability. Zheng and Ding (Ref 95) fabricated $\mathrm{HA} / \mathrm{TiO}_{2}$ coatings via APS and analyzed the in vitro adhesion of osteoblasts. It was observed that, after 7 days of culture, osteoblasts had completely spread on the coating surface and formed a continuous layer in which individual cells were not distinguishable. Lu et al. (Ref 96) also mixed HA and $\mathrm{TiO}_{2}$ and sprayed it onto a Ti substrate. In this case, titanium dioxide was not selected as a material to boost the interaction with body fluids/cells but rather to influence the mechanical properties of the coatings. The $\mathrm{TiO}_{2}$ acted as an obstacle to stress-induced microcracking, which contributed to the reduction of neartip stresses and decreased the CTE mismatch. This led to toughening and strengthening of the coated samples. Besides, improved bonding may also result because of certain interlocking of titanium dioxide particles and the oxide layer on the substrate surface. Sola and coworkers (Ref 97) worked with a similar kind of $\mathrm{HA} / \mathrm{TiO}_{2}$ coating but with a gradual transition in feedstock composition from $\mathrm{TiO}_{2}$ to HA. Very good adhesion was obtained at the interface because of the $\mathrm{TiO}_{2}$-rich region, whereas a more porous deposit was obtained at the top of the coating in the HA-rich region, which is supposed to provide good results for bone implants. Recently, Morks (Ref 98) selected a bioceramic material based on titania, zirconia, and silica. This different alternative aimed to use an APS coating without the poor mechanical properties of APS HA while benefiting from the importance of silica in bioactive materials for bonding of bone and muscle as well as as a cross-linking agent in connective tissues.

The importance of bond coats based on titanium dioxide for biocompatible hydroxyapatite coatings is not just limited to their mechanical properties. Heimann et al. (Ref 99) studied the Raman spectrum of APS HA coatings with and without a $\mathrm{TiO}_{2}$ bond coat; significant changes were found between the two spectra. Concretely, the presence of the bond coat resulted in predominant pure well-crystallized HA coatings. Titanium dioxide could be acting as a thermal barrier coating, reducing the fast quenching of impacting particles at high temperatures onto the cool substrate, which avoids the formation of "amorphous" calcium phosphate and other intermediates. Afterwards, the author reviewed the importance of these HA coatings supported by $\mathrm{TiO}_{2}$ bond coats (Ref 100).
Noncollagenous proteins such as osteonectin, osteocalcin, sialylated glycoproteins and proteoglycans that play important roles in bone remodeling are adsorbed onto these HA microcrystals, which act as adsorption sites. Besides this, the presence of the bond coat may reduce the release of cytotoxic heavy-metal ions from the implant body and may locally cushion forces induced by cyclic micromotions of the patient.

Furthermore, some authors have also chemically treated the obtained APS pure $\mathrm{TiO}_{2}$ coatings, inducing precipitation of apatite on the surface of the $\mathrm{TiO}_{2}$ sample, which favors its biocompatibility (Ref 101, 102). Contributions from an industrial point of view are also available: Lima et al. (Ref 103) disclosed a method for depositing nanostructured $\mathrm{TiO}_{2}$ powders by means of TS processes that could totally or partially melt the particles for application on bone implants, including technologies such as APS and high-velocity oxygen fuel spray.

Nanotextures present in $\mathrm{TiO}_{2}$ may increase the adsorption of proteins, leading to improved adhesion of osteoblasts, which explains why this material behaves successfully for bone implants. Hence, the expected transition from APS to $\mathrm{HVOF}$ for TS $\mathrm{TiO}_{2}$ coatings was accomplished. Following the tendency observed in APS $\mathrm{TiO}_{2} / \mathrm{HA}$ coatings, Gaona et al. (Ref 104) reinforced HVOF HA coatings with nano- $\mathrm{TiO}_{2}$ to boost their mechanical properties. Nanostructured $\mathrm{TiO}_{2}+20$ wt. $\%$ HA coatings exhibited adhesive-cohesive failure with an adhesion value of $68 \pm 14 \mathrm{MPa}$, which is much higher than values obtained previously for TS HA (31 MPa) and conventional $\mathrm{HVOF} \mathrm{TiO}_{2}+\mathrm{HA}$ coatings $(28 \mathrm{MPa})$. These results are in agreement with studies carried out by other authors (Ref 105-107). Besides, Singh and coworkers (Ref 108) also took advantage of the mechanical properties of titanium dioxide as a bond coat in $\mathrm{HA} / \mathrm{TiO}_{2}$ coatings deposited by high-velocity flame spray. Lima et al. (Ref 109) also sprayed nano- $\mathrm{TiO}_{2}$ and HA powders separately onto Ti-6Al-4V by means of HVOF and APS, respectively. The biocompatibility of the HVOF nano- $\mathrm{TiO}_{2}$ and APS HA coatings was compared by osteoblast cell culture fixed during 15 days for both samples. The results showed that the HVOF-sprayed nanostructured titania-coated sample exhibited higher osteoblast cell proliferation and adhesion compared with the usual APS HA coating, which may be attributed to the $\mathrm{TiO}_{2}$ nanoroughness present on the top surface of the coating. In a later work, the same authors studied the biocompatibility performance of HVOF coatings based on mixtures of nano- $\mathrm{TiO}_{2}$ and $\mathrm{HA}$ (Ref 110). Coatings of nano- $\mathrm{TiO}_{2}$ with 10 wt. \% HA exhibited bond strength levels above $77 \mathrm{MPa}$, which is twice that of APS HA coatings sprayed onto titanium alloy substrates. Compared with APS HA coatings, these results provide strong evidence that $\mathrm{HVOF}$ nano- $\mathrm{TiO}_{2}+$ 10 wt. \% HA coatings enabled: (i) superior growth and proliferation of cells, (ii) compatibility with osteoblastic lineages, and (iii) cell-substrate interaction. Energy-dispersive X-ray (EDX) line-scan analysis of the upper layers of the coatings showed microregions containing $\mathrm{Ti}, \mathrm{Ca}$, and $\mathrm{P}$ atoms. Although XRD did not detect $\mathrm{CaTiO}_{3}$ phase, the authors suggested the possibility of having a

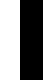


certain amount of this compound below the sensitivity threshold of the XRD analysis. The biological results in this study may be explained by the presence of $\mathrm{CaTiO}_{3}$ because it may help nucleation and growth of apatite, although porosity and residual stresses could also play an important role.

Biomedical coatings can also be obtained by HVOF using suspension feedstock in the same way as for photocatalytic applications. This concept could potentially be advanced by ensuring a nanotextured top surface of the sample instead of by avoiding the anatase-to-rutile phase transformation. However, remarkable contributions to the state of the art have not been reported yet.

On the other hand, Bolelli et al. (Ref 111) sprayed a bioactive glass based on $\mathrm{SiO}_{2}-\mathrm{CaO}-\mathrm{K}_{2} \mathrm{O}-\mathrm{P}_{2} \mathrm{O}_{5}$ by means of HVSFS onto titanium substrates. This study proposed the use of titanium dioxide as a bond coat to improve the deposition efficiency of the glass feedstock. A later work presented the obtained experimental results (Ref 112). In this case, an APS $\mathrm{TiO}_{2}$ bond coat was applied, which did not modify the overall microstructure of the HVSFS glass coating as happened with APS HA coatings. The adhesion between the bioactive glass and titanium substrate was poor due to the presence of microcracks in the interface region. Application of the $\mathrm{TiO}_{2}$ bond coat removed these undesired features, improving the adhesion of the glass coating. However, the lower, titanium dioxide coating did not have any effect in terms of the behavior of the coating when soaked in a simulated body fluid solution.

Fabrication of nanostructured anatase coatings may provide a surface that is able to enhance cell parameters. Thus, CGS faces the challenge of this new and interesting field of commercial exploitation for this technology, which must encourage professionals involved in CGS to maintain their efforts towards deposition and application of CGS nano- $\mathrm{TiO}_{2}$ coatings. Recently, Gardon et al. (Ref 113) coated polyetheretherketone (PEEK), which is biocompatible but has limited bioactivity, with well-bonded, thick CGS titanium coatings. The CGS spraying conditions were adequately optimized to avoid thermal softening of the polymer. Thus, the metallic particles were plastically deformed on impact onto the substrate and Ti coatings were built up. In a further work, this Ti coating was used as a bond coat to develop nanostructured anatase coatings by means of CGS (Ref 114). Again, the surface roughness of the bond coat together with its hardness and composition enhanced the deposition of nano- $\mathrm{TiO}_{2}$ particles, resulting in homogeneous ceramic coatings. Osteoblast cell cultures were placed onto the original PEEK polymer, CGS $\mathrm{Ti}$ bond coats, and CGS nano- $\mathrm{TiO}_{2}$ coatings. The results showed that the $\mathrm{CGS}$ nano- $\mathrm{TiO}_{2}$ coatings increased cell adhesion, proliferation, and differentiation by around 92 , 48, and $185 \%$, respectively, compared with the original PEEK substrate.

\subsection{Other Fields}

Although the creation of oxygen vacancies in the rutile crystal lattice due to $\mathrm{H}_{2}$ in the plasma jet may not be a desired phenomenon, it could result in interesting coating materials. Slightly defective nonstoichiometric rutile $\left(\mathrm{TiO}_{2-x}, x \leq 0.01\right)$ and reduced stoichiometries such as Magnéli phases $\left(\mathrm{Ti}_{n} \mathrm{O}_{2 n-1}, n=4-9\right)$ may exhibit very low electrical resistivities, especially the latter, reaching values comparable to that of graphite (Ref 115). Notably, the possibility of creating layers with low electrical resistivity while maintaining the corrosion resistance of a ceramic material opens many possibilities in the electrochemical field. Berger (Ref 116) reviewed this issue deeply, highlighting the new opportunities that titanium oxide can offer and the feasibility of using TS processes to obtain such an electrically conductive coating material. In addition, various patents related to this topic have been submitted. Hund et al. (Ref 117) used plasma spraying to prepare a metal anode based on $\mathrm{TiO}_{2-x} / \mathrm{Ti}_{n} \mathrm{O}_{2 n-1}$ on titanium pieces. The coated samples were used as low-cost electrodes in electrolysis of alkali chloride, offering a lifetime far superior to conventional materials. Later, Hill et al. (Ref 118) also disclosed the development of such coated electrodes. In a preferred embodiment, aluminum sheets were coated with electrically conductive titanium oxide by APS to a thickness of $120 \mu \mathrm{m}$. These coatings were applied as cathodes in electrodeposition of zinc. Successful performance for over $1000 \mathrm{~h}$ of operation was obtained, showing a current density of $450 \mathrm{~A} / \mathrm{m}^{2}$. In a recent publication, Garcia-Segura et al. (Ref 119) took advantage of an APS rutile coating containing the Magnéli phase $\mathrm{Ti}_{7} \mathrm{O}_{13}$ for solar photoelectrocatalytic degradation of Acid Orange 7 azo dye. Furthermore, Floristán et al. (Ref 120) dealt with deposition of $\mathrm{TiO}_{2}$ and $\mathrm{TiO}_{2} / \mathrm{NiC}$ rAlY powders onto glass-ceramic substrates for application as corrosion-resistant and electrically conductive resistive heaters. The influence of different spraying parameters was correlated with the accumulated residual stress and microstructure of the coatings. Residual stresses accumulated in the coating-substrate system may lead to a considerable amount of cracks, which act as electric resistances. The electrical resistivity of the coatings was reduced to $0.05 \Omega \mathrm{cm}$ after optimizing the spraying conditions. In a further work, Gardon et al. (Ref 121) deposited APS $\mathrm{TiO}_{2-x}$ coatings onto steel substrates and studied the mechanical properties and electrochemical performance of the samples. Obtained samples were based on rutile with a considerable quantity of oxygen vacancies in the crystal lattice and also a certain amount of Magnéli phases, which was correlated by means of X-ray diffraction and Raman spectroscopy; thinner coatings showed better adhesion strength. On the other hand, the electrochemical performance of APS $\mathrm{TiO}_{2-x}$-coated stainlesssteel electrodes was tested by means of cyclic voltammetry in different media such as sulfuric acid, methanesulfonic acid, and potassium hydroxide. Comparison between the original, uncoated stainless-steel electrodes and the coated samples demonstrated in all three distinct environments a potential range of operation when applying the APS $\mathrm{TiO}_{2-x}$ coatings onto the electrodes. Therefore, undesired electrochemical processes such as hydrogen evolution or oxygen evolution were delayed in both the cathode and anode, enlarging the applied potential and potentially enhancing the final performance of the battery. 
Furthermore, the capacity of rutile to accumulate oxygen vacancies in APS coatings and their corresponding reduced electrical resistivity may also be applied in other fields. As reviewed by Gardon and Guilemany (Ref 35), TS technologies can be used to develop metal oxide gas sensors to compete with established technologies in this field such as sol-gel processes or physical/chemical vapor deposition. Afterwards, the same authors demonstrated experimentally that APS coatings based on titanium dioxide with reduced stoichiometries have positive and reproducible responses to $\mathrm{NH}_{3(\mathrm{~g})}$ (Ref 122). In this study, the active layer of a gas sensor was built up from APS $\mathrm{TiO}_{2-x}$ coatings deposited onto a flexible thin polymer. Use of an optimal stand-off distance, number of cycles, and feeding rate resulted in wellbonded coatings on $50-\mu \mathrm{m}$-thick polymeric substrate, avoiding its damage. The active response of a metal oxide gas sensor is based on: (i) the receptor function, which determines the adsorption capacity of the solid; (ii) the transducer function, which controls the transformation of the chemical interaction into an electrical output; and (iii) the approachability, which defines the interaction between the inner grains and the target gas. In the above-mentioned study, the authors concluded that the large amount of oxygen vacancies present at the top surface of the APS $\mathrm{TiO}_{2-x}$ coating enhanced the receptor function; each oxygen vacancy may act as an active center for target gases.

Reducing fuels such as $\mathrm{H}_{2}$ are also used in HVOF. Therefore, together with high temperatures, conditions for altering the $\mathrm{TiO}_{2}$ stoichiometry towards $\mathrm{TiO}_{2-x}$ or $\mathrm{Ti}_{n} \mathrm{O}_{2 n-1}$ are possible, opening distinct applications in electronics or electrochemistry. Berger (Ref 116) compared the electrical resistivity of coatings obtained by APS and $\mathrm{HVOF}$ starting from $\mathrm{Ti}_{5} \mathrm{O}_{9}-\mathrm{Ti}_{6} \mathrm{O}_{11}$ powder. It was found that HVOF with hydrogen gas resulted in samples with almost half the resistivity of APS coatings, which could be attributed to greater preservation of the $\mathrm{O} / \mathrm{Ti}$ ratio. This makes HVOF very competitive with established APS procedures in industry for providing electrically conductive titanium dioxide coatings.

Znamirowski and coworkers (Ref 123) demonstrated that SPS $\mathrm{TiO}_{2-x}$ can be used as a field electron emitter for large-scale production in this application. Further studies related to the microstructural features of such coatings showed that the combination of electrically conductive Magnéli phases present in a nonconductive rutile/anatase matrix may be of special interest in this device (Ref 124). Besides, the performance of these coatings and the influence of the temperature on sprayed emitters obtained from fine-sized $\mathrm{TiO}_{2}$ and $\mathrm{TiO}_{2} / \mathrm{Al}_{2} \mathrm{O}_{3}$ powders were analyzed in later works (Ref 125, 126). As the temperature was increased, the permittivity and conductivity of rutile grains increased, leading to a decrease of the electron emission.

\section{Performance against Competing Technologies}

With the aim of understanding the competitiveness of functional TS $\mathrm{TiO}_{2}$ coatings compared with the most significant performance attained using different experimental methods, it is essential to overview the corresponding outcomes. Therefore, the purpose of this section is to present the most noteworthy results and significant variables in $\mathrm{TS} \mathrm{TiO}_{2}$ coatings for different active applications and compare them with available results obtained using other, competing coating technologies for the fabrication of functional $\mathrm{TiO}_{2}$ surfaces, such as sol-gel or physical vapor deposition (PVD). A general scheme of the situation can be presented, although in certain applications it is not so straightforward to compare different $\mathrm{TiO}_{2}$ coatings, especially when the information is obtained from different authors in separate works. Below, the foremost data obtained by distinct processes in different surveys regarding the final application of the coatings is presented, organized by charts.

\subsection{Degradation of Contaminants}

Photodegradation efficiencies for removing pollutants may depend on the target substances and the mechanisms involved. Moreover, heterogeneous catalysis in gaseous and liquid phases diverges significantly and must be adequately differentiated. Table 2 presents available obtained results for organic contaminants such as phenol in aqueous phase, which is of concern in chemical, petrochemical, and pharmaceutical applications. HVOF and HVSFS $\mathrm{TiO}_{2}$ coatings match or even improve upon the degradation rates obtained by standard sol-gel coating procedures. Available data prove the viability of $\mathrm{TS} \mathrm{TiO}_{2}$ as a photocatalytically active coating, and this result, combined with the advantageous technological features of TS in terms of productivity and ease of industrial scalability, can make TS the technique of choice for photocatalytic applications.

Furthermore, Table 3 presents results related to an inorganic contaminant in gaseous phase, viz. nitrogen oxides, which are especially controlled in urban atmospheres due to automotive emissions. Again, TS techniques demonstrate a capacity to decrease the concentration of the contaminant compared with different procedures such as sol-gel coating processes and also the incorporation of photoactive particles in cement.

Although phenol and $\mathrm{NO}_{x}$ photodegradation experiments have demonstrated that, the more anatase present in the coating, the greater the amount of pollutant removed, other authors have proved that the concentration of certain contaminants such as methylene blue can be reduced with a predominant presence of rutile (Ref 59), as reviewed in Sect. 4.1.1. Photodegradation of pollutants is not uniquely linked to the bandgap of the $\mathrm{TiO}_{2}$ material which leads to a different photoactivity of the catalyst, namely anatase versus rutile; the adsorption, surface reactivity, and desorption of a contaminant on the metal oxide are also of special interest, depending on surface features such as the roughness, thickness, porosity, grain size, specific surface, amount of $\mathrm{OH}$ groups on the surface, acidity/basicity, amount of oxygen vacancies, and other electrostatic considerations.

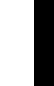


Table 2 Phenol degradation in aqueous phase

\begin{tabular}{|c|c|c|c|c|c|}
\hline Deposition technique & Starting concentration & Radiation & Coating composition & Degradation & References \\
\hline HVOF & $50 \mathrm{mg} / \mathrm{L}$ & UV light, $\lambda=360 \mathrm{~nm}$ & $57 \%$ anatase & $90 \%, 100 \mathrm{~min}$ & (Ref 72) \\
\hline HVSFS $^{\mathrm{a}}$ & $50 \mathrm{ppm}$ & UV light, $\lambda=360 \mathrm{~nm}$ & $100 \%$ rutile & $100 \%, 17 \mathrm{~min}$ & (Ref 127) \\
\hline Sol-gel & $21.6 \mathrm{ppm}$ & UV light, $\lambda \approx 335 \mathrm{~nm}$ & $74 \%$ anatase & $92 \%, 60 \mathrm{~min}$ & (Ref 128) \\
\hline Sol-gel $\mathrm{TiO}_{2}$ fibers & $50 \mathrm{mg} / \mathrm{L}$ & UV light, $\lambda=365 \mathrm{~nm}$ & $100 \%$ anatase & $87 \%, 480 \mathrm{~min}$ & (Ref 129) \\
\hline
\end{tabular}

Most relevant data in various studies

${ }^{\text {a }}$ The sprayed samples were annealed at $800{ }^{\circ} \mathrm{C}$ during $30 \mathrm{~min}$, and complete transformation from anatase to rutile was found. XRD patterns revealed a considerable peak attributed to oxides of the substrate that could influence the interaction with hydrogen peroxide, which would boost the final performance of the coating

Table 3 Degradation of nitrogen oxides in gaseous phase using $\mathrm{TiO}_{2}$ photocatalysts obtained by different coating technologies

\begin{tabular}{|c|c|c|c|c|c|}
\hline Deposition technique & Starting concentration & Radiation & Coating composition & Degradation & References \\
\hline SPS & $2 \mathrm{ppm}$ & UVA $30 \%$, UVB $4 \%$ & $100 \%$ anatase & $\begin{array}{c}50 \% \mathrm{NO} \text { and } 30 \% \\
\mathrm{NO}_{x}, 45 \mathrm{~min}\end{array}$ & (Ref 53) \\
\hline CGS & 1 ppm (50 \% humid.) & UV light, $\lambda=365 \mathrm{~nm}$ & $100 \%$ anatase & $80 \% \mathrm{NO}, 60 \mathrm{~min}$ & (Ref 130) \\
\hline Sol-gel & 40 ppm & $125 \mathrm{~W}, \mathrm{Hg}$ arc lamp & $75 \%$ anatase & $67 \% \mathrm{NO}, 40 \mathrm{~min}$ & (Ref 131) \\
\hline $\begin{array}{l}\text { Incorporated } \\
\text { into cement }\end{array}$ & 20 ppmv (50 \% humid.) & UV light, $\lambda=315-400 \mathrm{~nm}$ & $100 \%$ rutile & $60 \% \mathrm{NO}, 25 \mathrm{~min}$ & (Ref 132) \\
\hline
\end{tabular}

Table 4 Bioactivity on $\mathrm{TiO}_{2}$ surfaces obtained by different coating technologies

\begin{tabular}{|c|c|c|c|c|}
\hline Deposition technique & Cell type & Starting cell culture & Cell proliferation & References \\
\hline $\begin{array}{l}\mathrm{HVOF} \\
\mathrm{TiO}_{2} \text { nanowires (oxidation process) } \\
\text { Microarc oxidation }^{\mathrm{b}} \\
\text { Sol-gel }\end{array}$ & $\begin{array}{l}\text { Human mesenchymal stem cells } \\
\text { Human osteosarcoma cells } \\
\text { MG63 cells } \\
\text { Human osteosarcoma cells }\end{array}$ & $\begin{array}{l}1.5 \times 10^{6} \text { cells }(\text { day } 0) \\
5 \times 10^{4} \text { cells }(\text { day } 0) \\
2.5 \times 10^{4} \text { cells }(\text { day } 5) \\
10^{4} \text { cells }(\text { day } 0)\end{array}$ & $\begin{array}{l}7 \times 10^{6} \text { cells }(\text { day } 14) \\
9 \times 10^{4} \text { cells }(\text { day } 35) \\
9.5 \times 10^{4} \text { cells }(\text { day } 7) \\
2 \times 10^{4} \text { cells }(\text { day } 5)\end{array}$ & $\begin{array}{l}(\text { Ref } 110,133) \\
(\text { Ref } 134) \\
(\text { Ref } 135) \\
(\text { Ref } 136)\end{array}$ \\
\hline
\end{tabular}

Table 5 Performance of DSSC; $\mathrm{TiO}_{2}$ layer obtained by different coating technologies

\begin{tabular}{|c|c|c|c|c|}
\hline Deposition technique & Coating thickness, $\mu \mathrm{m}$ & Radiation & Conversion efficiency, \% & References \\
\hline VCS & 15 & Xe lamp, $100 \mathrm{~mW} / \mathrm{cm}^{2}$ & $2.4-4.9^{\mathrm{a}}$ & $(\operatorname{Ref} 85)$ \\
\hline Spray pyrolysis deposition & $6,12,20,30$, and 50 & $\mathrm{AM} 1.5,100 \mathrm{~mW} / \mathrm{cm}^{2}$ & 5.1 & (Ref 137) \\
\hline Sol-gel & 10 & Diffuse daylight & 12 & (Ref 138) \\
\hline Doctor-blade method & $6-10$ & $\mathrm{AM} 1.5,100 \mathrm{~mW} / \mathrm{cm}^{2}$ & 7.9 & (Ref 139) \\
\hline${ }^{\mathrm{a}}$ After annealing & & & & \\
\hline
\end{tabular}

\subsection{Biomedical Applications}

Replacing diseased tissues and articular joints with biomaterials is a very attractive application market due to the global demand and large investments in this field. TS $\mathrm{TiO}_{2}$ coatings are commonly applied, but this is not the only industrial procedure for coating implants with metal oxide. Wide heterogeneity can be found in the results presented in the literature. Therefore, the evolution and proliferation of different cells on $\mathrm{TiO}_{2}$ coatings obtained by distinct experimental techniques are presented in Table 4. Functional HVOF $\mathrm{TiO}_{2}$ results are competitive with different coating processes such as microarc oxidation or sol-gel.

\subsection{Conversion of Solar Energy}

Although DSSC is a relatively new technology for exploiting solar energy and some advances in materials and dyes are required, it is oddly the application that has 
Table $6 \mathrm{TiO}_{2}$ bactericidal coatings obtained by different techniques and the most relevant data

\begin{tabular}{|c|c|c|c|c|}
\hline Deposition technique & Bacterium & Radiation & Degradation & References \\
\hline HVOF & P. aeruginosa & White light, $\lambda=380-750 \mathrm{~nm}$ & $24 \%, 120 \mathrm{~min}$ & (Ref 81) \\
\hline $\mathrm{CGS}^{\mathrm{a}}$ & $P$. aeruginosa & UVA light, $\lambda \leq 385 \mathrm{~nm}$ & $99.99 \%, 5 \mathrm{~min}$ & (Ref 82) \\
\hline Sol-gel route ${ }^{a}$ & $P$. aeruginosa & UV light, $\lambda=356 \mathrm{~nm}$ & $99.99 \%, 60 \mathrm{~min}$ & (Ref 140) \\
\hline Jet spray screen print & $P$. aeruginosa & UV LED & $99.99 \%, 25 \mathrm{~min}$ & (Ref 141) \\
\hline
\end{tabular}

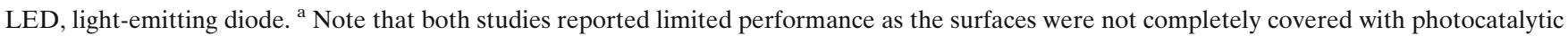
particles. This could be improved using CGS to apply nano- $\mathrm{TiO}_{2}$ powders synthesized for homogeneous deposition to create chemical bonds with the substrate, which would lead to complete coverage

received less attention in terms of $\mathrm{R}+\mathrm{D}+\mathrm{i}$ of TS technologies. The thickness of the coating is especially critical in this case and has a huge influence on the conversion efficiency. Therefore, it must be taken into account that the distinct collected values cannot be directly compared but rather give a perspective on the present situation. Table 5 compiles relevant information related to different deposition techniques and efficiencies. In this case, the efficiency of the DSSC obtained by VCS was less than half that achieved by common sol-gel cells, confirming the importance of centering more effort on this line of research to achieve satisfactory results.

\subsection{Disinfection of Surfaces}

Biomedical restrictions require surfaces free of bacteria to achieve disinfected atmospheres. Therefore, bactericidal products may help to achieve appropriate working environments and can also be applied as coatings on surgical equipment. In addition, their application can spread to other markets where sterilization of materials is required, which enhances interest in successfully deposited TS $\mathrm{TiO}_{2}$ coatings. Table 6 presents relevant data; the photocatalytic activities of TS coatings again demonstrate improved results compared with competing technologies. Outstanding results were found for CGS photocatalysts, which may even be below the optimal value due to the fact that the substrates were not completely coated with photoactive $\mathrm{TiO}_{2}$ particles.

\section{Conclusions}

Use of titanium dioxide as a ceramic material has not been limited to the protection of substrates in surface manufacturing. Advances in surface engineering related to many different functional applications involving this metal oxide have not gone unnoticed by the TS technology community. Consequently, over more than a decade of effort has been applied and interesting solutions obtained to enable the scale-up of these coating processes towards industrial development.

Chiefly, the ability of titanium dioxide to create an electron-hole pair when irradiating the solid with UV light has driven interest in TS to develop photocatalytic surfaces that are able to degrade different contaminants and bacteria. Nonetheless, the heat entailed by this process presents two main disadvantages: (i) loss of anatase phase, which is presumed to be more active, and (ii) increase of grain size, which reduces the specific area of the solid. Despite this, the reviewed literature suggests that pure anatase coatings are not the optimum material; a certain synergic effect is found when rutile is also present. Therefore, APS fed by suspensions or solutions may overcome this issue. HVOF spray can work in this regard by adjusting the spraying conditions or even also using liquid feedstock. In this way, research groups and companies using these processes may apply this material to address photocatalytic applications, because sufficient success and benefits have been reported. Nevertheless, recent progress in CGS has demonstrated that this method is able to deposit homogeneous, well-bonded nanostructured anatase coatings. More investigation on such powders is still required, but this could result in an attractive trend with a new commercial coating technique and standard material being established, which could replace other TS technologies and even competing processes.

Regarding bone implants, addition of nano- $\mathrm{TiO}_{2}$ to $\mathrm{HA}$ improves the mechanical properties of TS coatings. Furthermore, nanostructured metal oxides can play a key role in boosting protein adsorption, leading to enhanced cell adhesion. It is supposed that hydrophilic $\mathrm{TiO}_{2}$ phases such as anatase could help to induce this behavior, but more research must be carried out to demonstrate this. Therefore, in spite of the temperatures involved, TS processes that are able to produce coatings with nanosized $\mathrm{TiO}_{2}$ grains such as SPS and HVOF are attracting increased business interest. CGS has already proved its ability to produce implant coatings with compositions based on nanostructured titanium dioxide, although in vivo tests and further development are awaited.

Solar energy conversion and other applications of nano- $\mathrm{TiO}_{2}$ demand a major advance in TS technology to reach successful efficiencies. Moreover, the electrical resistivity of titanium dioxide with reduced stoichiometry combined with its corrosion resistance must be considered, and interesting lines of research are open that could contribute to many different devices, especially related to electrochemistry.

\section{Acknowledgments}

The authors wish to thank the Generalitat de Catalunya for financial support of this research project (2009 SGR 00390). 


\section{References}

1. J.J. Polidor, Plasma Spray Coated Ceramic Bodies and Method of Making Same, Patent Number 4877705, 1989

2. A. Makoto, N. Akio, and M. Takashi, Wear Resistant Thermal Spray Coating, Patent Number JP2004232035, 2004

3. M. Rosso, A. Scrivani, D. Ugues, and S. Bertini, Corrosion Resistance and Properties of Pump Pistons Coated with Hard Materials, Int. J. Refract. Met. Hard Mater., 2001, 19(1), p 45-52

4. Y. Wang, S. Jiang, M. Wang, S. Wang, T. Danny Xiao, and P.R. Strutt, Abrasive Wear Characteristics of Plasma Sprayed Nanostructured Alumina/Titania Coatings, Wear, 2000, 237(2), p 176185

5. Y. Liu, T.E. Fischera, and A. Dent, Comparison of HVOF and Plasma-Sprayed Alumina/Titania Coatings-Microstructure, Mechanical Properties and Abrasion Behavior, Surf. Coat. Technol., 2003, 167(1), p 68-76

6. J. Kitamura, H. Ibe, F. Yuasa, and H. Mizuno, Plasma Sprayed Coatings of High-Purity Ceramics for Semiconductor and FlatPanel-Display Production Equipment, J. Therm. Spray Technol., 2008, 17(5-6), p 878-886

7. E. Turunen, T. Varis, T.E. Gustafsson, J. Keskinen, T. Fält, and S.-P. Hannula, Parameter Optimization of HVOF Sprayed Nanostructured Alumina and Alumina-Nickel Composite Coatings, Surf. Coat. Technol., 2006, 200, p 4987-4994

8. E. Turunen, T. Varis, S.-P. Hannula, A. Vaidya, A. Kulkarni, J. Gutleber, S. Sampath, and H. Herman, On the Role of Particle State and Deposition Procedure on Mechanical, Tribological and Dielectric Response of High Velocity Oxy-Fuel Sprayed Alumina Coatings, Mater. Sci. Eng. A, 2006, 415, p 1-11

9. H. Singh, M.S. Grewal, H.S. Sekhon, and R.G. Rao, Sliding Wear Performance of High-Velocity Oxy-Fuel Spray $\mathrm{Al}_{2} \mathrm{O}_{3} / \mathrm{TiO}_{2}$ and $\mathrm{Cr}_{2} \mathrm{O}_{3}$ Coatings, Proc. Inst. Mech. Eng. J, 2008, 222(4), p 601-610

10. R. Ahmed, N.H. Faisal, A.M. Paradowska, and M.E. Fitzpatrick, Residual Strain and Fracture Response of $\mathrm{Al}_{2} \mathrm{O}_{3}$ Coatings Deposited via APS and HVOF Techniques, J. Therm. Spray Technol., 2012, 21(1), p 23-40

11. G. Bolelli, L. Lusvarghi, T. Manfredini, F. Pighetti Mantini, R. Polini, E. Turunen, T. Varis, and S.-P. Hannula, Comparison between Plasma- and HVOF-Sprayed Ceramic Coatings. Part I: Microstructure and Mechanical Properties, Int. J. Surf. Sci. Eng., 2007, 1(1), p 38-61

12. G. Bolelli, L. Lusvarghi, T. Varis, E. Turunen, M. Leoni, P. Scardi, C.L. Azanza-Ricardo, and M. Barletta, Residual Stresses in HVOF-Sprayed Ceramic Coatings, Surf. Coat. Technol., 2008, 202(19), p 4810-4819

13. T.S. Sidhu, R.D. Agrawal, and S. Prakash, Hot Corrosion of Some Superalloys and Role of High-Velocity Oxy-Fuel Spray Coatings-a Review, Surf. Coat. Technol., 2005, 198(1-3), p 441-446

14. K.A. Khor, Z.L. Dong, and Y.W. Gu, Plasma Sprayed Functionally Graded Thermal Barrier Coatings, Mater. Lett., 1999, 38(6), $p$ 437-444

15. L. Wang, Y. Wang, X.G. Sun, J.Q. He, Z.Y. Pan, Y. Zhou, and P.L. Wu, Influence of Pores on the Thermal Insulation Behavior of Thermal Barrier Coatings Prepared by Atmospheric Plasma Spray, Mater. Des., 2011, 32(1), p 36-47

16. P. Ctibor, J. Sedláček, and K. Neufuss, Influence of Chemical Composition on Dielectric Properties of $\mathrm{Al}_{2} \mathrm{O}_{3}$ and $\mathrm{ZrO}_{2}$ Plasma Deposits, Ceram. Int., 2003, 29(5), p 527-532

17. P. Ctibor, J. Sedláček, K. Neufuss, and P. Chrásk, Dielectric Relaxation in Calcium Titanate-Containing Ceramics Prepared by Plasma Spraying, Ceram. Int., 2003, 29(8), p 955-960

18. A. Joly, P. Brun, J. Lacombe, G. Tricot, and A. Denoirjean, Structural Characterization of an Electrically Insulating Diffusion Barrier on a Plasma-Sprayed Ceramic for Severe Environment Applications, Surf. Coat. Technol., 2013, 220, p 204 208

19. D. Michels, J. Hadeler, and V.J.H. Lienhard, High-Heat-Flux Resistance Heaters from VPS and HVOF Thermal Spraying, Exp. Heat Transf., 1998, 11(4), p 341-359

20. http://www.iluka.com/_uploads/documents/Briefing\%20Material/ ILU\%20Mineral\%20Sands\%20Products\%20Attributes\%20and\% 20Applications.pdf. Accessed 12 March 2013
21. L. Pawłowski, Strategic Oxides for Thermal Spraying: Problems of Availability and Evolution of Prices, Surf. Coat. Technol., 2013, 220, p 14-19

22. U. Diebold, The Surface Science of Titanium Dioxide, Surf. Sci. Rep., 2003, 48, p 53-229

23. E.P. Meagher and G.A. Lager, Polyhedral Thermal Expansion in the $\mathrm{TiO}_{2}$ Polymorphs: Refinement of the Crystal Structures of Rutile and Brookite at High Temperature, Can. Miner., 1979, 17, p 77-85

24. Y. Li and T. Ishigaki, Thermodynamic Analysis of Nucleation of Anatase and Rutile from $\mathrm{TiO}_{2}$ Melt, J. Cryst. Growth, 2002, 242, p 511-516

25. http://rruff.info/doclib/hom/rutile.pdf. Accessed 18 May 2013

26. http://rruff.info/doclib/hom/anatase.pdf. Accessed 18 May 2013

27. http://www.matweb.com/. Accessed 16 May 2013

28. R.H. West, G.J.O. Beran, W.H. Green, and M. Kraft, FirstPrinciples Thermochemistry for the Production of $\mathrm{TiO}_{2}$ from $\mathrm{TiCl}_{4}$, J. Phys. Chem. A, 2007, 111(18), p 3560-3565

29. http://www.icis.com/Articles/2007/11/07/9076547/titanium-dioxidetio2-production-and-manufacturing-process.html. Accessed 04/ $11 / 2013$

30. N. Tjitra Salim, M. Yamada, H. Nakano, K. Shima, and M. Fukumoto, The Synthesis of Titanium Dioxide Powders for Cold Spray, Thermal Spray 2011: Proceedings of the International Thermal Spray Conference, B.R. Marple, Ed., September 27-29, 2011 (Hamburg, Germany), ASM International, 2011

31. G.J. Yang, C.J. Li, F. Han, W.Y. Li, and A. Ohmori, Low Temperature Deposition and Characterization of $\mathrm{TiO}_{2}$ Photocatalytic Film through Cold Spray, Appl. Surf. Sci., 2008, 254, p 3979-3982

32. New Materials, Sulzer Technical Review 2/2013, ISSN: 16609042

33. L. Pawlowski, The Science and Engineering of Thermal Spray Coatings, 2nd ed., Wiley, New York, 2008, ISBN 978-0-47149049-4

34. A. Ohmori, K.C. Park, M. Inuzuka, Y. Arata, K. Inoue, and N. Iwamoto, Electrical Conductivity of Plasma-Sprayed Titanium Oxide (Rutile) Coatings, Thin Solid Films, 1991, 201(1), p 1-8

35. M. Gardon and J.M. Guilemany, A Review on Fabrication, Sensing Mechanisms and Performance of Metal Oxide Gas Sensors, J. Mater. Sci., 2013, 24(5), p 1410-1421

36. M. Gardon and J.M. Guilemany, The Influence of Titanium Suboxides in Thermal Sprayed Coatings, Thermal Spray 2012: Proceedings from the International Thermal Spray Conference and Exposition, B.R. Marple, Ed., May 21-24, 2012 (Houston, USA), ASM International 2012, p 622-626

37. H. Zhang and J.F. Banfield, Thermodynamic Analysis of Phase Stability of Nanocrystalline Titania, J. Mater. Chem., 1998, 8(9), p 2073-2076

38. V.V. Sobolev, J.M. Guilemany, J. Nutting, and S. Joshi, High Velocity Oxy-fuel Spraying: Theory, Structure-Property Relationships and Applications, Maney Ed., London, 2004, ISBN 1902653726

39. A. Killinger, R. Gadow, G. Mauer, A. Guignard, R. Vassen, and D. Stoever, Review of New Developments in Suspension and Solution Precursor Thermal Spray Processes, J. Therm. Spray Technol., 2011, 20(4), p 677-695

40. R. Gadow, A. Killinger, M. Kuhn, D. Lopez, Thermal Spraying of a Suspension Comprises Supplying the Suspension to the Combustion Chamber or Expansion Nozzle of a Torch, Patent Number: DE102005038453 A1, 2007

41. V. Champagne, The Cold Spray Materials Deposition Process: Fundamentals and Applications, Woodhead Publishing in Materials, 2007, ISBN: 1420066706

42. A. Papyrin, Cold Spray Technology, Elsevier, 2007, ISBN: 0080451551

43. H. Gutzmann, S. Freese, F. Gärtner, and T. Klassen, Layer Formation of Cold-Sprayed Ceramic Titanium Dioxide Layers on Metal Surfaces, Proceedings on International Thermal Spray Conference, Singapore, 2010

44. H. Gutzmann, S. Freese, F. Gärtner, and T. Klassen, Cold Gas Spraying of Ceramics Using the Example of Titanium Dioxide, Proceedings on International Thermal Spray Conference, Hamburg, Germany, 2011 
45. M. Yamada, H. Isago, K. Shima, H. Nakano, and M. Fukumoto, Deposition of $\mathrm{TiO}_{2}$ Ceramic Particles on Cold Spray Process, Thermal Spray 2010: Global Solutions for Future Applications Proceedings of the International Thermal Spray Conference, B.R. Marple, Ed., May 3-5, 2010 (Singapore), ASM International, Singapore

46. N. Tjitra Salim, M. Yamada, H. Isago, K. Shima, H. Nakano, and M. Fukumoto, The Understanding on Adhesion Mechanism of Cold Sprayed $\mathrm{TiO}_{2}$ Coating, Thermal Spray 2011: Proceedings of the International Thermal Spray Conference, B.R. Marple, Ed., September 27-29, 2011 (Hamburg, Germany), ASM International, 2011

47. A. Fujishima and K. Honda, Electrochemical Photolysis of Water at a Semiconductor Electrode, Nature, 1972, 238, p 37-38

48. A. Fujishima and X. Zhang, Titanium Dioxide Photocatalysis: Present Situation and Future Approaches, C. R. Chim., 2006, 9(5-6), p 750-760

49. B. Normand, V. Fervel, C. Coddet, and V. Nikitine, Tribological Properties of Plasma Sprayed Alumina-Titania Coatings: Role and Control of the Microstructure, Surf. Coat. Technol., 2000, 123, p 278-287

50. M. Bounazef, S. Guessasma, G. Montavon, and C. Coddet, Effect of APS Process Parameters on Wear Behaviour of AluminaTitania Coatings, Mater. Lett., 2004, 58, p 2451-2455

51. G. Bertrand, N. Berger-Keller, C. Meunier, and C. Coddet, Evaluation of Metastable Phase and Microhardness on Plasma Sprayed Titania Coatings, Surf. Coat. Technol., 2006, 200, p 50135019

52. N. Berger-Keller, G. Bertrand, C. Filiatre, C. Meunier, and C. Coddet, Microstructure of Plasma-Sprayed Titania Coatings Deposited from Spray-Dried Powder, Surf. Coat. Technol., 2003, 168, p 281-290

53. F.L. Toma, G. Bertrand, S. Begin, C. Meunier, O. Barres, D. Klein, and C. Coddet, Microstructure and Environmental Functionalities of $\mathrm{TiO}_{2}$-Supported Photocatalysts Obtained by Suspension Plasma Spraying, Appl. Cat. B, 2006, 68, p 74-84

54. F.-L. Toma, G. Bertrand, S.O. Chwa, C. Meunier, D. Klein, and C. Coddet, Comparative Study on the Photocatalytic Decomposition of Nitrogen Oxides Using $\mathrm{TiO}_{2}$ Coatings Prepared by Conventional Plasma Spraying and Suspension Plasma Spraying, Surf. Coat. Technol., 2006, 200, p 5855-5862

55. M.C. Bordes, M. Vicent, A. Moreno, R. Moreno, A. Borrell, M.D. Salvador, and E. Sánchez, Microstructure and Photocatalytic Activity of APS Coatings Obtained from Different $\mathrm{TiO}_{2}$ Nanopowders, Surf. Coat. Technol., 2012, 220, p 179-186

56. M. Bozorgtabar, M. Rahimipour, M. Salehi, and M. Jafarpour, Structure and Photocatalytic Activity of $\mathrm{TiO}_{2}$ Coatings Deposited by Atmospheric Plasma Spraying, Surf. Coat. Technol., 2011, 205, p 229-231

57. T. Kanazawa and A. Ohmori, Behavior of $\mathrm{TiO}_{2}$ Coating Formation on PET Plate by Plasma Spraying and Evaluation of Coating's Photocatalytic Activity, Surf. Coat. Technol., 2005, 197(1), p 45-50

58. F.-L. Toma, G. Bertrand, D. Klein, C. Coddet, and C. Meunier, Nanostructured Photocatalytic Titania Coatings Formed by Suspension Plasma Spraying, J. Therm. Spray Technol., 2006, 15(4), p 587

59. S. Kozerski, F.-L. Toma, L. Pawlowski, B. Leupolt, L. Latka, and L.-M. Berger, Suspension Plasma Sprayed $\mathrm{TiO}_{2}$ Coatings Using Different Injectors and Their Photocatalytic Properties, Surf. Coat. Technol., 2010, 205, p 980-986

60. P. Ctibor, V. Stengl, I. Pís, T. Zahoranova, and V. Nehasil, Plasma Sprayed $\mathrm{TiO}_{2}$ : the Influence of Power of an Electric Supply on Relations among Stoichiometry, Surface State and Photocatalytic Decomposition of Acetone, Ceram. Int., 2012, 38(4), p 3453-3458

61. E. Bannier, G. Darut, E. Sánchez, A. Denoirjean, M.C. Bordes, M.D. Salvador, E. Rayón, and H. Ageorges, Microstructure and Photocatalytic Activity of Suspension Plasma Sprayed $\mathrm{TiO}_{2}$ Coatings on Steel and Glass Substrates, Surf. Coat. Technol., 2011, 206, p 378-386

62. P. Ctibor, Z. Pala, J. Sedlacek, V. Stengl, T. Zahoranova, and V. Nehasil, Titanium Dioxide Coatings Sprayed by a Water-Stabi- lized Plasma Gun (WSP) with Argon and Nitrogen as the Powder Feeding Gas: Differences in Structural, Mechanical and Photocatalytic Behavior, J. Therm. Spray Technol., 2012, 21(3-4), p 425434

63. G. Mauer, A. Guignard, and R. Vaßen, Plasma Spraying of Efficient Photoactive $\mathrm{TiO}_{2}$ Coatings, Surf. Coat. Technol., 2013, 220, p 40-43

64. Y.-F. Lin, K.-L. Tung, Y.-S. Tzeng, J.- Chen, and K.-S. Chang, Rapid Atmospheric Plasma Spray Coating Preparation and Photocatalytic Activity of Macroporous Titania Nanocrystalline Membranes, J. Memb. Sci., 2012, 389, p 83-90

65. V. Snapkauskiene, V. Valincius, and V. Grigaitiene, Preparation and Characterization of $\mathrm{TiO}_{2}$-Based Plasma-Sprayed Coatings for NOx Abatement, Catal. Today, 2012, 191, p 154-158

66. M. Vicent, E. Sánchez, A. Moreno, and R. Moreno, Preparation of High Solids Content Nano-Titania Suspensions to Obtain Spray-Dried Nanostructured Powders for Atmospheric Plasma Spraying, J. Eur. Ceram. Soc., 2012, 32(1), p 185-194

67. R.S. Lima and B.R. Marple, From APS to HVOF Spraying of Conventional and Nanostructured Titania Feedstock Powders: a Study on the Enhancement of the Mechanical Properties, Surf. Coat. Technol., 2006, 200, p 3428-3437

68. A. Ibrahim, R.S. Lima, C.C. Berndt, and B.R. Marple, Fatigue and Mechanical Properties of Nanostructured and Conventional Titania $\left(\mathrm{TiO}_{2}\right)$ Thermal Spray Coatings, Surf. Coat. Technol., 2007, 201, p 7589-7596

69. L. Toma, N. Keller, G. Bertrand, D. Klein, and C. Coddet, Elaboration and Characterization of Environmental Properties of $\mathrm{TiO}_{2}$ Plasma Sprayed Coatings, Int. J. Photoenergy, 2003, 5, p 141-145

70. F.-L. Toma, G. Bertrand, S.O. Chwa, D. Klein, H. Liao, C. Meunier, and C. Coddet, Microstructure and Photocatalytic Properties of Nanostructured $\mathrm{TiO}_{2}$ and $\mathrm{TiO}_{2}-\mathrm{Al}$ Coatings Elaborated by HVOF Spraying for the Nitrogen Oxides Removal, Mater. Sci. Eng. A, 2006, 417, p 56-62

71. J. Colmenares-Angulo, S. Zhao, C. Young, and A. Orlov, The Effects of Thermal Spray Technique and Post-deposition Treatment on the Photocatalytic Activity of $\mathrm{TiO}_{2}$ Coatings, Surf. Coat. Technol., 2009, 203(15), p 2150-2156

72. G.-J. Yang, C.-J. Li, F. Han, and A. Ohmori, Microstructure and Photocatalytic Performance of High Velocity Oxy-Fuel Sprayed $\mathrm{TiO}_{2}$ Coatings, Thin Solid Films, 2004, 466, p 81-85

73. G.-J. Yang, C.-J. Li, Y.-Y. Wang, and C.-X. Li, Dominant Microstructural Feature over Photocatalytic Activity of High Velocity Oxy-Fuel Sprayed $\mathrm{TiO}_{2}$ Coating, Surf. Coat. Technol., 2007, 202, p 63-68

74. K. Nakade, J. Yasuoka, A. Ohmori, The Development of Nanophotocatalytic $\mathrm{TiO}_{2}$ Coatings by Thermal Spraying, Nov. Mat. Proc. Adv. Electromag. En. Sour., 2005, p 407-410

75. R. Gadow, A. Killinger, and J. Rauch, Introduction to HighVelocity Suspension Flame Spraying (HVSFS), J. Therm. Spray Technol., 2008, 17(5-6), p 655

76. G. Bolelli, V. Cannillo, R. Gadow, A. Killinger, L. Lusvarghi, and J. Rauch, Properties of High Velocity Suspension Flame Sprayed (HVSFS) $\mathrm{TiO}_{2}$ Coatings, Surf. Coat. Technol., 2009, 203(12-15), p $1722-1732$

77. F.-L. Toma, L.-M. Berger, D. Jacquet, D. Wicky, I. Villaluenga, Y.R. de Miguel, and J.S. Lindeløv, Comparative Study on the Photocatalytic Behaviour of Titanium Oxide Thermal Sprayed Coatings from Powders and Suspensions, Surf. Coat. Technol., 2009, 203, p 2150-2156

78. F.-L. Toma, L.-M. Berger, C.C. Stahr, T. Naumann, and S. Langner, Microstructures and Functional Properties of Suspension-Sprayed $\mathrm{Al}_{2} \mathrm{O}_{3}$ and $\mathrm{TiO}_{2}$ Coatings: an Overview, J. Therm. Spray Technol., 2010, 19(1-2), p 262-274

79. H. Gutzmann, J.-O. Kliemann, R. Albrecht, F. Gärtner, T. Klassen, F.-L. Toma, L.-M. Berger, and B. Leupolt, Thermal Spray 2010: Global Solutions for Future Applications Proceedings of the International Thermal Spray Conference, B.R. Marple, Ed., May 3-5, 2010 (Singapore), ASM International, Singapore

80. M. Gardon, C. Fernández-Rodríguez, D. Garzón-Sousa, J.M. Doña-Rodríguez, S. Dosta, I.G. Cano and J.M. Guilemany, Photocatalytic Activity of Nanostructured Anatase Coatings 
Obtained by Cold Gas Spray, J. Therm. Spray Technol, 2014. To be published

81. B. Jeffery, M. Peppler, R.S. Lima, and A. McDonald, Bactericidal Effects of HVOF-Sprayed Nanostructured $\mathrm{TiO}_{2}$ on Pseudomonas aeruginosa, J. Therm. Spray Technol., 2010, 19(1-2), p 344349

82. J.-O. Kliemann, H. Gutzmann, F. Gärtner, T. Klassen, and H. Gabriel, Cold Spraying for Titanium Dioxide Coatings with High Photocatalytic Bactericidal Activity, Thermal Spray 2010: Global Solutions for Future Applications Proceedings of the International Thermal Spray Conference, B.R. Marple, Ed., May 3-5, 2010 (Singapore), ASM International, Singapore

83. S.-Q. Fan, G.-J. Yang, C.-J. Li, G.-J. Liu, C.-X. Li, and L.-Z.

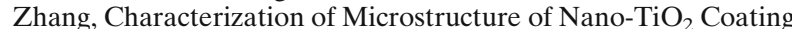
Deposited by Vacuum Cold Spraying, J. Therm. Spray Technol., 2006, 15(4), p 513

84. S.-Q. Fan, C.-J. Li, C.-X. Li, G.-J. Liu, G.-J. Yang, and L.-Z. Zhang, Preliminary Study of Performance of Dye-Sensitized Solar Cell of Nano-TiO 2 Coating Deposited by Vacuum Cold Spraying, Mater. Trans., 2006, 47(7), p 1703-1709

85. S.-Q. Fan, C.-J. Li, G.-J. Yang, L.-Z. Zhang, J.-C. Gao, and Y.-X. $\mathrm{Xi}$, Fabrication of Nano-TiO 2 Coating for Dye-Sensitized Solar Cell by Vacuum Cold Spraying at Room Temperature, J. Therm. Spray Technol., 2007, 16(5-6), p 893-897

86. G.J. Yang, K.-X. Liao, C.J. Li, S.-Q. Fan, C.-X. Li, and S. Li, Formation of Pore Structure and Its Influence on the Mass Transport Property of Vacuum Cold Sprayed $\mathrm{TiO}_{2}$ Coatings Using Strengthened Nanostructured Powder, J. Therm. Spray Technol., 2011, 21(3-4), p 505-513

87. http://www.metalfinishing.com/view/6310/current-trends-in-coldspray-technology-looking-at-the-future/. Accessed 12/04/2013

88. M. Long and H.J. Rack, Titanium Alloys in Total Joint Replacement: a Materials Science Perspective, Biomaterials, 1998, 19(18), p 1621-1639

89. L.N. Wu, B.R. Genge, and R.E. Wuthier, Micropatterned $\mathrm{TiO}_{2}$ Effects on Calcium Phosphate Mineralization, Mater. Sci. Eng. C, 2009, 29(8), p 2355-2359

90. K.S. Brammer, S. Oh, C.J. Frandsen, and S. Jin, Biomaterials and Biotechnology Schemes Utilizing $\mathrm{TiO}_{2}$ Nanotube Arrays, Biomaterials Science and Engineering, Prof. Rosario Pignatello (Ed.), ISBN: 978-953-307-609-6, InTech. http://www.intechopen.com/ books/biomaterials-science-and-engineering/biomaterials-andbiotechnologyschemes-utilizing-tio2-nanotube-arrays. Accessed 18 March 2013

91. R.S. Lima and B.R. Marple, Thermal Spray Coatings Engineered from Nanostructured Ceramic Agglomerated Powders for Structural, Thermal Barrier and Biomedical Applications: a Review, J. Therm. Spray Technol., 2007, 40(16), p 40-63

92. J. He, W. Zhou, X. Zhou, X. Zhong, X. Zhang, P. Wan, B. Zhu, and W. Chen, The Anatase Phase of Nanotopography Titania Plays an Important Role on Osteoblast Cell Morphology and Proliferation, J. Mater. Sci., 2008, 19, p 3465-3472

93. D. Yamamoto, K. Arii, K. Kuroda, R. Ichino, M. Okido, and A. Seki, Osteoconductivity of Superhydrophilic Anodized $\mathrm{TiO}_{2}$ Coatings on Ti Treated with Hydrothermal Processes, J. Biomater. Nanobiotechnol., 2013, 4(1), p 45-52

94. S. Rossi, N. Moritz, T. Tirri, T. Peltola, S. Areva, M. Jokinen, R.-P. Happonen, and T. Närhi, Comparison between Sol-Gel-Derived Anatase- and Rutile-Structured $\mathrm{TiO}_{2}$ Coatings in Soft-Tissue Environment, J. Biomed. Mater. Res. A, 2007, 82A(4), p 965-974

95. X.B. Zheng and C.X. Ding, Characterization of Plasma-Sprayed Hydroxyapatite $/ \mathrm{TiO}_{2}$ Composite Coatings, J. Therm. Spray Technol., 2000, 9(4), p 520-525

96. Y.-P. Lu, M.-S. Li, S.-T. Li, Z.-G. Wang, and R.-F. Zhu, PlasmaSprayed Hydroxyapatite + Titania Composite Bond Coat for Hydroxyapatite Coating on Titanium Substrate, Biomaterials, 2004, 25(18), p 4393-4403

97. V. Cannillo, L. Lusvarghi, and A. Sola, Production and Characterization of Plasma-Sprayed $\mathrm{TiO}_{2}$-Hydroxyapatite Functionally Graded Coatings, J. Eur. Ceram. Soc., 2008, 28(11), p 2161-2169

98. M.F. Morks, Plasma Spraying of Zirconia-Titania-Silica BioCeramic Composite Coating for Implant Application, Mater. Lett., 2010, 64(18), p 1968-1971
99. R.B. Heimann, H.V. Tran, and P. Hartmann, Laser-Raman and Nuclear Magnetic Resonance (NMR) Studies on Plasma-Sprayed Hydroxyapatite Coatings: Influence of Bioinert Bond Coats on Phase Composition and Resorption Kinetics in Simulated Body Fluid, Materwiss. Werksttech., 2003, 34(12), p 1163-1169

100. R.B. Heimann, Thermal Spraying of Biomaterials, Surf. Coat. Technol., 2006, 201, p 2012-2019

101. X. Zhao, X. Liu, C. Ding, and P.K. Chu, In Vitro Bioactivity of Plasma-Sprayed $\mathrm{TiO}_{2}$ Coating after Sodium Hydroxide Treatment, Surf. Coat. Technol., 2006, 200(18-19), p 5487-5492

102. D. Chen, E.H. Jordan, M. Gell, and M. Wei, Apatite Formation on Alkaline-Treated Dense $\mathrm{TiO}_{2}$ Coatings Deposited Using the Solution Precursor Plasma Spray Process, Acta Biomater., 2008, 4(3), p 553-559

103. R. Lima, B. Marple, H. Li, and K.A. Khor, Biocompatible Thermal Spray Coating Made from a Nanostructured Feedstock, Patent Number US2006199024, 2006

104. M. Gaona, R.S. Lima, and B.R. Marple, Nanostructured Titania/Hydroxyapatite Composite Coatings Deposited by High Velocity Oxy-Fuel (HVOF) Spraying, Mater. Sci. Eng. A, 2007, 458(1-2), p 141-149

105. H. Melero, J. Fernández, S. Dosta, and J.M. Guilemany, Caracterización de nuevos recubrimientos biocompatibles de hidroxiapatita- $\mathrm{TiO}_{2}$ obtenidos mediante Proyección Térmica de Alta Velocidad, Bol. Soc. Esp. Cer. Vid., 2011, 50(2), p 59-64

106. H. Melero, J. Fernández, and J.M. Guilemany, Recubrimientos biocompatibles de HAp y titania, Rev. Biomech., 2011, 19, p $35-48$

107. H. Li, K.A. Khor, and P. Cheang, Titanium Dioxide Reinforced Hydroxyapatite Coatings Deposited by High Velocity Oxy-Fuel (HVOF) Spray, Biomaterials, 2002, 23, p 85-91

108. T.P. Singh, H. Singh, and H. Singh, Characterization, Corrosion Resistance, and Cell Response of High-Velocity FlameSprayed HA and $\mathrm{HA} / \mathrm{TiO}_{2}$ Coatings on $316 \mathrm{~L}$ SS, J. Therm. Spray Technol., 2012, 21(5), p 917-927

109. R.S. Lima, B. Marple, H. Li, and K.A. Khor, Biocompatible Nanostructured High-Velocity Oxyfuel Sprayed Titania Coating: Deposition, Characterization, and Mechanical Properties, J. Therm. Spray Technol., 2006, 15(4), p 623-627

110. R.S. Lima, S. Dimitrievska, M.N. Bureau, B.R. Marple, A. Petit, F. Mwale, and J. Antoniou, HVOF-Sprayed Nano $\mathrm{TiO}_{2}-$ HA Coatings Exhibiting Enhanced Biocompatibility, J. Therm. Spray Technol., 2010, 19(12), p 343-363

111. G. Bolelli, V. Cannillo, R. Gadow, A. Killinger, L. Lusvarghi, and J. Rauch, Processing and Characterisation of HighVelocity Suspension Flame Sprayed (HVSFS) Bioactive Glass Coatings, Ceram. Silik., 2010, 54(1), p 1-7

112. D. Bellucci, G. Bolelli, V. Cannillo, R. Gadow, A. Killinger, L. Lusvarghi, A. Sola, and N. Stiegler, High Velocity Suspension Flame Sprayed (HVSFS) Potassium-Based Bioactive Glass Coatings with and without $\mathrm{TiO}_{2}$ Bond Coat, Surf. Coat. Technol., 2012, 206(19-20), p 3857-3868

113. M. Gardon, A. Latorre, M. Torrell, S. Dosta, J. Fernández, and J.M. Guilemany, Cold Gas Spray Titanium Coatings onto a Biocompatible Polymer, Mater. Lett., 2013, 106, p 97-99

114. M. Gardon, H. Melero, N. García-Giralt, S. Dosta, I.G. Cano and J.M. Guilemany, Enhancing the Bioactivity of Polymeric Implants by Means of Cold Gas Spray Coatings, J. Biomed. Mater. Res. B, 2013. To be published

115. P.C.S. Hayfield, Development of a New Material: Monolithic $\mathrm{Ti}_{4} \mathrm{O}_{7}$ Ebonex ${ }^{\circledR}$ Ceramic, Royal Society of Chemistry, Cambridge, 2002, ISBN 0854049843

116. L.M. Berger, Titanium Oxide-New Opportunities for an Established Coating Material, Proceedings on International Thermal Spray Conference, Osaka, Japan, p 934

117. H. Hund, H. Schäfer, and D. Bergner, Method of Making Long-Term Electrode for Electrolytic Processes, Patent Number US4140813, 1979

118. A. Hill and K. Ellis, Method of Applying Conductive Coating, Patent Number WO97/27344, 1997

119. S. Garcia-Segura, S. Dosta, J.M. Guilemany, and E. Brillas, Solar Photoelectrocatalytic Degradation of Acid Orange 7 Azo Dye Using a Highly Stable $\mathrm{TiO}_{2}$ Photoanode Synthesized by 
Atmospheric Plasma Spray, Appl. Catal. B, 2013, 132-133, p $142-150$

120. M. Floristán, R. Fontarnau, A. Killinger, and R. Gadow, Development of Electrically Conductive Plasma Sprayed Coatings on Glass Ceramic Substrates, Surf. Coat. Technol., 2010, 205(4), p 1021-1028

121. M. Gardon, S. Dosta, J.M. Guilemany, M. Kourasi, B. Mellor, and R. Wills, Improved, High Conductivity Titanium Suboxide Coated Electrodes Obtained by Atmospheric Plasma Spray, J. Power Sources, 2013, 238, p 430-434

122. M. Gardon, O. Monereo, G. Vescio, S. Dosta, A. Cirera, and J.M. Guilemany, New Procedures for Building-Up the Active Layer of Gas Sensors on Flexible Polymers, Surf. Coat. Technol., 2013, 235, p 848-852

123. R. Tomaszek, Z. Znamirowski, L. Pawlowski, and A. Wojnakowski, Temperature Behavior of Titania Field Emitters Realized by Suspension Plasma Spray, Surf. Coat. Technol., 2006, 201, p 2099-2102

124. R. Tomaszek, Z. Znamirowski, L. Pawlowski, and J. Zdanowski, Effect of Conditioning on Field Emission of Suspension Plasma Sprayed $\mathrm{TiO}_{2}$ Coatings, Vacuum, 2007, 81, p 1278-1282

125. Z. Znamirowski, W. Czarczynski, L. Pawlowski, and A. Wojnakowski, Temperature Influence and Hot Electrons in Field Electron Emission from Composite Layers Deposited by Air Plasma Spraying of Powders and Suspensions, J. Vac. Sci. Technol. B, 2007, 25(5), p 1664-1670

126. Z. Znamirowski and M. Ladaczek, Lighting Segment with Field Electron Titania Cathode Made Using Suspension Plasma Spraying, Surf. Coat. Technol., 2008, 202, p 4449-4452

127. G.-J. Yang, C.-J. Li, F. Han, and S.-F. Mao, Preparation of $\mathrm{TiO}_{2}$ Photocatalyst by Thermal Spraying with Liquid Feedstock, Proceedings on International Thermal Spray Conference, Orlando, USA, 2003

128. G. Goutailler, C. Guillard, S. Daniele, and L.G. HubertPfalzgraf, Low Temperature and Aqueous Sol-Gel Deposit of Photocatalytic Active Nanoparticulate $\mathrm{TiO}_{2}$, J. Mater. Chem., 2003, 13, p 342-346

129. S. Yao, Y. Zhang, Z. Shi, and S. Wang, Physical Properties of Nano Titania Hollow Fibers and Their Photocatalytic Activity in the Decomposition of Phenol, Russ. J. Phys. Chem. A, 2013, 87(1), p 69-73

130. M. Yamada, H. Isago, H. Nakano, and M. Fukumoto, Cold Spraying of $\mathrm{TiO}_{2}$ Photocatalyst Coating with Nitrogen Process Gas, J. Therm. Spray Technol., 2010, 19(6), p 1218-1223
131. H. Wang, Z. Wu, W. Zhao, and B. Guan, Photocatalytic Oxidation of Nitrogen Oxides Using $\mathrm{TiO}_{2}$ Loading on Woven Glass Fabric, Chemosphere, 2007, 66(1), p 185-190

132. J.V.S. de Melo and G. Trichês, Evaluation of the Influence of Environmental Conditions on the Efficiency of Photocatalytic Coatings in the Degradation of Nitrogen Oxides $\left(\mathrm{NO}_{x}\right)$, Build. Env., 2012, 49, p 117-123

133. S. Dimitrievska, M.N. Bureau, J. Antoniou, F. Mwale, A. Petit, R.S. Lima, and B.R. Marple, Titania-Hydroxyapatite Nanocomposite Coatings Support Human Mesenchymal Stem Cells Osteogenic Differentiation, J. Biomed. Mater. Res., 2011, 98A(5), p 576-588

134. B. Dinan, D. Gallego-Perez, H. Lee, D. Hansford, and S.A. Akbar, Thermally Grown $\mathrm{TiO}_{2}$ Nanowires to Improve Cell Growth and Proliferation on Titanium Based Materials, Ceram. Int., 2013, 39(5), p 5949-5954

135. D. Wei and Y. Zhou, Preparation, Biomimetic Apatite Induction and Osteoblast Proliferation Test of $\mathrm{TiO}_{2}$-Based Coatings Containing P with a Graded Structure, Ceram. Int., 2009, 35(6), p 2343-2350

136. H.-W. Kim, Y.-H. Koh, L.-H. Li, S. Lee, and H.-E. Kim, Hydroxyapatite Coating on Titanium Substrate with Titania Buffer Layer Processed by Sol-Gel Method, Biomaterials, 2004, 25(13), p 2533-2538

137. M. Okuya, K. Nakade, D. Osa, T. Nakano, G.R.A. Kumara, and S. Kaneko, Fabrication of Dye-Sensitized Solar Cells by Spray Pyrolysis Deposition (SPD) Technique, J Photochem. Photobiol. A, 2004, 164, p 167-172

138. B. O'Reagan and M. Grätzel, A Low Cost, High Efficiency Solar Cell Based on Dye Sensitized Colloidal $\mathrm{TiO}_{2}$ Films, Nature, 1991, 353, p 737-740

139. T. Yamaguchi, N. Tobe, D. Matsumoto, T. Nagai, and H. Arakawa, Highly Efficient Plastic-Substrate DyeSensitized Solar Cells with Validated Conversion Efficiency of 7.6\%, Sol. Energy Mater. Sol. Cells, 2010, 94(5), p 812-816

140. K.P. Kühn, I.F. Chaberny, K. Massholder, M. Stickler, V.W. Benz, H.-G. Sonntag, and L. Erdinger, Disinfection of Surfaces by Photocatalytic Oxidation with Titanium Dioxide and UVA Light, Chemosphere, 2003, 53(1), p 71-77

141. J.W. MacFarlane, H.F. Jenkinson, and T.B. Scott, Sterilization of Microorganisms on Jet Spray Formed Titanium Dioxide Surfaces, Appl. Catal. B, 2011, 106(1-2), p 181-185 